\begin{tabular}{|c|c|c|c|}
\hline Article Info & RESEARCH ARTICLE & ARAŞTIRMA MAKALESİ & \\
\hline Title of Article & \multicolumn{2}{|c|}{$\begin{array}{c}\text { Evaluation of women's behaviours in urban } \\
\text { public spaces in terms of security: the } \\
\text { sample of Muratpaşa Neighbourhood, } \\
\text { Erzurum }\end{array}$} & \\
\hline $\begin{array}{l}\text { Corresponding } \\
\text { Author }\end{array}$ & \multicolumn{2}{|c|}{$\begin{array}{l}\text { Süleyman TOY } \\
\text { Atatürk Üniversitesi, Mimarlık ve Tasarım Fakültesi, Şehir ve Bölge Planlama Bölümü, } \\
\text { stoy58@gmail.com }\end{array}$} & \\
\hline $\begin{array}{l}\text { Received Date } \\
\text { Accepted Date }\end{array}$ & \multicolumn{2}{|c|}{$\begin{array}{l}10.05 .2021 \\
14.09 .2021\end{array}$} & \\
\hline Doi Number & \multicolumn{2}{|l|}{ https://doi.org/10.35674/kent.935411 } & \\
\hline Author / Authors & $\begin{array}{l}\text { Büşra KADIOĞLU AKGÜL } \\
\text { Süleyman TOY }\end{array}$ & $\begin{array}{l}\text { ORCID: 0000-0003-2390-0901 } \\
\text { ORCID: 0000-0002-3679-280X }\end{array}$ & \\
\hline How to Cite & \multicolumn{2}{|c|}{$\begin{array}{l}\text { AKGÜL, B. K., ve TOY, S. (2021). Kentsel Mekânlarda Kadın Davranışlarının } \\
\text { Güvenlik Kapsamında Değerlendirilmesi: Erzurum Kenti Muratpaşa Mahallesi } \\
\text { Örneği, Kent Akademisi, Volume, 14, Issue 3, Pages,789-810 }\end{array}$} & $\begin{array}{l}\text { Kent Akademisi } \\
\text { Urban Academy }\end{array}$ \\
\hline
\end{tabular}

\title{
Kentsel Mekânlarda Kadın Davranışlarının Güvenlik Kapsamında Değerlendirilmesi: Erzurum Kenti Muratpaşa Mahallesi Örneği
}

Büşra KADIOĞLU AKGÜL ${ }^{1}$ Süleyman TOY ${ }^{2}$

\begin{abstract}
:
Social structure and difference shape cause segmentation in urban spaces, which is important for the formation of city. In the case of space separation, women have to live in spaces alienated by others. The manner not respecting women's living spaces is caused by their dislocated identity. Security factor affects women's use of urban spaces. Security concern is identified through women's manner of using urban spaces. Female users feel an obligation towards using urban areas without limitations. They are prevented from using the spaces experiencing all their features because of feeling insecure. Such unfavourable conditions prevent women from benefiting from the advantages of public spaces. In the underdeveloped societies, it is generally banned or perceived to be a guilt for women to pass through the areas where males stay densely or to stay out late at night. Women's physical existence in urban public spaces is more limited than men in a city depending on security perception. In this study, security problems of women are evaluated in Muratpaşa, Yakutiye, Erzurum as a contribution to the urban studies. Area reflects historical and traditional social structure. Analyses were performed at different times to discover user behaviors. Woman population in the neighborhood is larger than male but can hardly use it. Coffeehouses are placed for watching football or performing leisure activities out of the buildings. Women prefer different walking routes. This continues at nights and poor lighting and dark streets increase insecure feeling for women. Women's rights to be urban and benefit from the city's possibilities are abused. Through evaluation, opinions were expressed to strengthen women's ties with cities. In the
\end{abstract}

\footnotetext{
${ }^{1}$ Atatürk University, Architecture and Design Faculty, Department of Interior Architecture, busrakadiogluu@ gmail.com

${ }^{2}$ Atatürk University, Architecture and Design Faculty, Department of Urban and Regional Planning, stoy58@ gmail.com
} 
conclusion part of the study, a qualitative evaluation was completed to describe opinions on the approaches to strengthen women's ties with urban spaces. This study dealt with the city, women and security, is expected to contribute to literature and create an important ground for the implementation of the necessary regulations for female users in urban spaces.

KEYWORDS: city, woman, gender, security, urban public space, user behaviour, coffee - shop culture

ÖZ:

Toplumun yapısı ve farklılıkları mekânda ayrışmalara neden olmaktadır. Bu durum kentin şekillenmesinde önemlidir. Mekân ayrışmalarında kadın başkalarının karar verdiği sınırlarda yaşamak durumundadır. Kadınların yaşam alanlarına gereken saygının gösterilmemesi onun ötelenen bir kimlik altına alınmasından kaynaklanmaktadır. Bunun yanında kadınların kent mekânlarını kullanmasında güvenlik faktörünün etkisi üst düzeydedir. Kadınların yaşadıkları güvenlik endişesi kent mekânlarını kullanma şekilleriyle anlaşılır. Kadın kullanıcıların kenti sınırlılıklar ile kullanmak zorunda hissetmeleri, mekânları tüm nitelikleriyle kullanmalarına engel olmakta ve davranışları güvensizlik hissi ile bütünleşmektedir. Bu durum kadınların kentsel mekânlardan faydalanmalarını dolaylı olarak engellemiştir. Ayrıca kadınların erkek yoğunluğu olan alanlara gitmesi veya geç saatlerde dışarıda bulunması durumu toplumda genellikle bir yasak gibi algılanmaktadır. Bu sebeple kentte kadınların hareket alanı erkeklerden daha dar olup kent içinde güvenli mekân algısı azalmaktadır. Bu çalışmada Türkiye'de son dönemde önemli düzeye ulaşan kent çalışmalarına bir katkı olarak Erzurum Yakutiye İlçesinde bulunan Muratpaşa Mahallesi kentsel mekânında kadınların güvenlik problemleri okunacaktır. Mevcut kentsel mekânda kadınların güvenlik problemlerinin var olup olmadığı ve varsa hangi etkenler nedeniyle bu problemlerin oluştuğunu belirlemek çalışmanın ana amacıdır. Muratpaşa mahallesi doku olarak Erzurum kentinin tarihini ve toplumsal yapısını yansıtmakta, kentin merkezi olması sebebiyle de önemli bir inceleme alanı olma durumundadır. Çalışma alanında kullanıcı davranışlarını keşfetmek amacı ile farklı zamanlarda çeşitli analizler yapılmıştır. Bu mahallede yaşayan kadın nüfusunun erkek nüfusundan fazla olmasına rağmen kadınların alanı neredeyse hiç kullanamadığı analizler ile yapılan sayımlar ve anket doğrultusunda yapılan görüşmeler sonucunda tespit edilmiştir. Muratpaşa mahallesinde yoğun olarak görülen kahvehane kültürünün etkisiyle erkeklerin mekân kullanımının yüksek seviyeye ulaştığı alanda kadınlar evlerine giderken bile farklı yürüyüş rotaları oluşturmak zorunda kaldığı görülmüştür. Bu durum çalışmanın yürütüldüğü kentsel mekânda, cinsiyetçi ayrışmanın görülen en açık halidir. Mahallenin gece kullanımında da bu durum devam etmekte olup yapılan analizler sonucu tespit edilen yetersiz aydınlatma ve karanlık sokaklar kadınların güvensiz olma hissini artıran etmenlerdir. Yürütülen tüm analizlerin sonucunda kadınların kentli olma ve kentten faydalanma haklarını istismar edildiği görülmektedir. Çalışmanın sonuç bölümünde nitelikli şekilde bir değerlendirme yapılarak kadınların kentsel mekânlarla olan bağlarını güçlendirecek yaklaşımlar üzerine görüşler bildirilmiştir. Kent, kadın ve güvenlik konusunu kesiştiren bu çalışma ile literatüre katkı sağlanacak, kentsel mekânlarda kadın kullanıcılar için gereken düzenlemelerin yürütülebilmesinde önemli bir zemin oluşturulacaktır.

ANAHTAR KELIMELER: kent, kadın, cinsiyet, güvenlik, kentsel mekân, kullanıcı davranışı, kahvehane kültürü

\section{‘'Kentsel Mekânlarda Kadın Davranışlarının Güvenlik Kapsamında Değerlendirilmesi: Erzurum Kenti Muratpaşa Mahallesi Örneği”’}

\section{GİRIŞ:}

Kentler içinde yaşayan insanları etkileyen dokulardır. Bu insanlar da kent dokusunu benzer biçimde etkilemektedir. Tarih boyunca bu etkileşim devam etmiş ve kent kentlilere, kentliler de kente bir kimlik kazandırmıştır. Etkileşimin en yoğun yaşandığı yer ise sosyal çevrenin bulunduğu kentsel mekânlardır. Kentsel mekân en basit tanımıyla kentin yapılarla çevrelenmiş; ancak yapıların dışında kalan bölümleri olup toplumun kent içerisinde sosyalleşebilmesini sağlayan unsurdur (Eşkinat, 1992). Kentlilerin erişimine sunulan ve ortak bir sosyal alana sahip olan alanlar kentsel mekânları oluşturmaktadır (Erdönmez \& Çelik, 2016). Kentsel mekânlar kentin sosyal kimliğinin, politik rekabetin ve mücadelenin birleştiği alanları temsil etmektedirler (Low \& Smith, 2006). Bu mekânların şekillenmesinde toplumun 
kültürel yapısı ve çeşitlilikleri de önemli ölçüde etkili olmaktadır. Böylelikle toplumda oluşan değişken yapılaşma kentsel mekânlarda da ayrışmaların oluşmasına neden olmaktadır.

Kentlerde sosyo - ekonomik, sosyo - kültürel ve mekânsal çeşitlilik ne kadar fazla ise o denli çok yönlü kamusal alanlar karşımıza çıkar. Kamusal alanların kentsel mekânlarda edindiği oransal büyüklük, bireylerin kendini gerçekleştirmeleri ve karakterlerinin şekillenmesiyle doğrudan ilgilidir. Dolayısıyla, kentlerdeki kamusal alan varlığı ve bu alanlarda gerçekleştirilen ortak etkinlikler kentlerdeki sosyal hayatın canlılığına doğrudan etki eder. Bu büyük önemine rağmen kamusal alanların kentsel mekânlarda kendine yer bulamaması kentsel mekânların sosyallik, ruh ve beden sağlığı ve güvenlik gibi faktörler açısından olumsuz özellikler taşımasına neden olur. Bunun yanında topluma ve bireylere kazançtan öte zarar ve tehdit oluşturur (Erdönmez \& Çelik, 2016). Nüfus büyüklükleri artan kentlerde de sosyal anlamda kontrolün kaybolduğu bilinmektedir (Aksoy, 2007). Bu nedenle, kontrolü azalan kentsel mekânlarda güvenlik faktörünün niteliği de zayıflamaktadır. Böylelikle kentlilerin kentsel mekânları kullanımı önemli derecede etkilenmektedir.Nitelikli bir kent yapısı için Lynch tarafından beş teori belirlenmiştir. Bu teoriler:

- Sağlıklı bir çevre oluşturmak için belirlenen canlılık,

- Mekânda var olan kimlik hissini gösteren hissiyat,

- Mekâna uyumluluk,

- Kullanıcıların mekâna, kaynağa, aktivitelere erişimi ve

- Kullanılan kentsel mekânda çevrenin kontrolüdür (Lynch, 1960).

Belirlenen beş teori aslında kentsel mekânda cinsiyet ve güvenlik kavramlarını da yakından etkilemektedir. Kullanıcıların mekâna rahatça erişebilir olması, bulundukları kentsel mekânda kendini güvende hissedebilmesi ve eşit haklarla kullanabilen canlı bir çevrenin kurgulanmış olması mekân kullanımını nitelikli hale getirecektir.

Kentsel hayat kentlilerin bir taraftan toplumsallığını gerçekleştirmesi için zemin oluştururken, öte yandan da toplum içinde cinsiyete yönelik kavramları da üretmektedir. Böylelikle kentler kendi sosyo-kültürel yapısıyla kadın ve erkeğe farklı mekânlarda, farklı özgürlükler, fırsatlar ve güvenliklerine yönelik hizmetler sunmaktadır. Bu nedenle kentsel mekân cinsiyetlendirilmiş bir alan olarak da karşımıza çıkmaktadır (Aktaş, 2017).

Kentsel mekânlar, kentlilerin zihninde güvenlik seviyelerine göre sınıflandırılmaktadır. Bu durum kadınların güvenlik tehditleri sebebiyle bazı mekânlardan uzak durmalarını zorunlu kılmaktadır. Kadınlar bu tür mekân kullanımlarına zorunlu oldukları durumlarda da bir erkeğin muhtemelen yaşamayacağı şekilde korku ve endişe hissetmektedirler (Aktaş, 2017). Böyle algılar ile yaşayan toplumlarda kadınlar genel sosyal yapıda başkaları (siyasi ve toplumsal etkiler, geleneksel algılar vb. nedenler) tarafından karar verilmiş sınırlar ile yaşamaya alıştırılmış durumdadır. Kadınların yaşam alanlarına gereken nitelik ve değer verilmemesi de kadının ötelenen bir kimlik altına girmesine sebebiyet vermektedir. Erkeklerin egemen olduğu toplum yapısındaki kentsel mekânda bu egemenliğin bir sonucu olarak, toplumsal şiddet düzeylerinde artışların görülmesiyle bu kentsel mekânların kadın kullanıcılar için güvensiz alanlar olduğuna yönelik çeşitli algılar oluşmuştur. Bu tür algılar da kadın kullanıcıların gündelik hayatlarını ve kişisel özgürlüklerini sınırlandırmaktadır (Güney vd., 2020). Cinsiyet ayrımcılığına bağlı olarak şiddetin yaşandığı kentlerde, neredeyse nüfusun tamamını etkileyen hoşgörüsüz davranışlar görülmesi sıradan ve yaygın bir durumdur. Kent içinde bulunan kamusal alanlar, sokaklar, parklar ve alışveriş merkezi gibi ortak kullanım alanları bir grup için güvensiz ise tüm kentliler için güvensizdir. Bir kent tüm kullanıcılarının güvenliğini sağlayabilmelidir (Doan, 2007).

Sokağın ve kentsel mekânların çoğunlukla erkeklerin gündüz ve gece özgür bir şekilde kullandığı, çocukluktan başlayarak önce oyunlarla daha sonra ise arkadaş gruplarıyla sokakta zaman geçirmeleri göz önüne alınınca genellikle erkeklere ait olan bir ortam olduğu düşüncesi oluşmaktadır (Temizarabacı, 2005). Ayrıca 16. yüzyıldan itibaren Osmanlı'da yerini alan kahvehaneler de erkeklerin kullandığı aktif mekânlar olmuştur (Ediz, 2008). Osmanlı'dan günümüze kadar uzanan ve erkeklerin mekân kullanımını yüksek seviyelere taşıyan kahvehane kültürü de kentsel mekân kullanımında cinsiyetçi ayrışmalara sebep olmaktadır. Kahvehaneler kentsel mekânlarda geniş yer tutarak toplumsal yaşamın tam merkezinde yer almakta ve kentsel çevreyi etkilemektedir.

Kent, kadın ve güvenlik kapsamlı çalışmalara bir katkı olarak, bu çalışmayla; kadın kullanıcıların kentsel mekânları kullanımı güvenlik kavramı kapsamında incelenmiş ve bu mekânlarda bulunan kahvehanelerin de kadın kullanıcıların kentsel mekânları kullanımına güvenlik açısından olan etkisi üzerine çıkarımlar yapılmıştır. Erzurum Yakutiye

Evaluation of Women's Behaviours in Urban Public Spaces in terms of Security: the Sample of Muratpaşa Neighbourhood, Erzurum

Journal of Urban Academy | Volume: 14 Issue: 3 | ISSN: 2146-9229

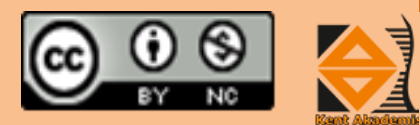


İlçesinde bulunan Muratpaşa Mahallesi kentsel mekânında yürütülen çalışmada, alanı kullanan kadınların güvenlik problemlerinin var olup olmadığı ve varsa hangi etkenler nedeniyle bu problemlerin oluştuğunu belirlemek çalışmanın ana amacidir.

\section{Kent, Kadın ve Güvenlik İlișkisi}

Toplumsal bir gereksinim olan güvenlik hissi, insanları birlikte yaşamaya iten nedenlerin başında gelmektedir. Sosyal bilimci Abraham Maslow' un ihtiyaçlar piramidinde ihtiyaçları sıralarken; "fizyolojik, güvenlik, toplumsal saygı ve kendini gerçekleştirme", olarak önem sırası gözettiği görülmektedir (Maslow, 1968). İhtiyaçlar piramidi incelendiğinde beslenme ihtiyacının ardından güvenli bir ortamda barınma isteği gelmektedir. Temel bir ihtiyaç niteliğinde olan güvenlik kavramı kentsel boyutta da önem taşımaktadır. Kentsel güvenlik kavramı kentte yaşayan bir bireyin ya da bir grubun, kentsel yaşamında ihtiyaçlarını karşılarken ve ilişkilerini yürütürken bunları güvenlik içinde yapabilmesinin mümkün kılınmasıdır. Kentsel mekânlar aslında içerisinde güvenliğin tam olduğu ve yaşayanlarına güven hissi sunan mekânlar olmak zorundadırlar (Kaya, 2008).

Yüzyıllar boyunca kadın ve sokak ilişkisi olumsuz çağrışımlarla çevrelenmiş ve dışarıya çıkan kadın toplumun düzenine karşı bir tehdit olarak algılanmıştır. $\mathrm{Bu}$ durumun kökeninde toplumsal rollerin cinsiyete göre inşa edilmesiyle birlikte, kamusal alanların ve özel alanların bu algıya göre düzenlenmesi yatmaktadır. Modern toplumsal hayatın işleyişinin temelini oluşturan özel ve kamusal ayrımı, kadın ve mekân etkileşiminin en belirgin biçimde somutlaştığı alanlardandır. Bu ayrım, kentsel ölçekte ele alındığında; kadınların kentteki davranıșlarının, pratiklerinin ve hareket alanlarının sosyo-mekânsal sınırlılıklarını açıklamaya imkân vermektedir (Tuncer, 2015). Toplumsal cinsiyete dayalı eşitsizlikler ve cinsiyetçi roller sebebiyle, kadınlar ve erkekler kenti farklı şekillerde deneyimlemektedirler.

Günümüzde artan nüfuslu büyük kentlerde karmaşıklaşan kent hayatı sürekli bir sorun üretim merkezi haline gelmektedir. Kentsel mekânlarda gerçekleşen ve ürkütücü boyutlara ulaşan, adi suçtan terör suçuna kadar çeşitleri artan suçlar kentsel güvenlik kavramına yeni bir boyut getirmiştir (Kaypak, 2016). Bu mekânlar farklı toplumsal kitleler ile heterojen yapılı olmakta ve yoksulluk, işsizlik, suç gibi unsurların artış göstermesi nedeniyle de kadınlar için güvensizliğin, korku ve endişenin merkezi haline gelmektedir. Kentlerin özellikle belli saatleri ve belli mekânları kadınlar açısından dışlayıcı olarak algılanmaktadır. Böylelikle, kadınların çalışma yaşamına dâhil olabilmek amacıyla erkeklere göre daha seçici ve dikkatli davranmaları gerekir (Aktaş, 2017).

Kadınların taşıdıkları güvenlik endişesi kentsel mekânları kullanma şekilleriyle okunabilmektedir. Örneğin; kadın kullanıcıların kenti sınırlılıklar ile kullanmak zorunda hissetmeleri, mekânları tüm nitelikleriyle kullanmalarına engel olmaktadır. Böylelikle, davranışları güvensizlik hissi ile bütünleşmektedir. Gündüzleri kenti sınırlı olarak kullanan kadın, toplumda ''kışkırtıcı'" olarak görüldüğü için geceleri tecavüz korkusuyla kentsel mekânlardan uzaklaşmak zorunda hissetmektedir (Griffin, 1986). Bu güvenlik problemi kadınlar için bir kadın sorunu olarak değerlendirilmek yerine, kentin kurgusundaki eksikliklerden / hatalardan kaynaklanmaktadır. Bu durum karşısında çözüm ise; herkesin kentsel mekanları adil şekilde kullanabilmesini sağlayacak kent haklarının sağlanması ve kentlerin bu anlayışla kurgulanmasıdır (Güney vd., 2020).

Kentsel mekânlar, insanların zihinlerinde güvenlik derecelerine göre sınıflandırılmaktadır. Kadınların büyük bir kısmı güvenlik tehditleri sebebiyle bazı mekânlardan uzak durmaktadır. Birçok kadın kendilerine toplum tarafından yasaklanmış, erkek kullanıcıların yoğun olduğu mekânlara gitmeyi ve geç saatlerde sokaklara çıkmayı istememektedir. Çünkü toplum tarafından zihinlerde, bu durumun ' normal olan (?)'” olduğuna yönelik algılar vardır. Kentsel mekânlarda bütün kadınlar için belirli bir sınırlandırma varken bazı kadınların bu sınırlandırmadan aldıkları pay ise daha fazladır. Kültürel unsurlar, sınıfsal aidiyet, inanç ve gelenek gibi kavramlar kadınların bu alanları kullanım süresini ve biçimini belirlemektedir (Cantek vd., 2014; aktaran Aktaş, 2017). Erkeklerin kullandığı ve ürettiği mekân olan kahvehanelere "kadın" olarak girmenin veya tam tersi olarak kadınlar lokaline "erkek" olarak girmenin mahremiyet ihlali olarak algılanması, cinsiyetçi ayrışmanın mekânsal boyutunu göstermektedir (Aktaş, 2017). Bu gibi durumların, kadınların kentteki alanları kullanmalarına ve bu alanlardan faydalanmalarına engel olduğu açıktır. Kentli kadınların hareket ve sosyal alanı erkeklerden daha dar olup güvenli mekân algısı gün geçtikçe azalmaktadir. 
Kentteki tüm kamu hizmetlerinden faydalanarak fiziksel çevresini aktif bir şekilde iyileştiren ve diğer kentlilerle iletişimi olan kadınlar güvenlik duygusuna sahiptir (Women in Cities International, 2008). Bir kadının mutluluğu, toplumun genelinde refah ve mutluluk düzeylerinin sağlanması için bir ölçüttür (Kirk, 2010). Bu nedenle kadınların toplum içerisinde üstlendiği vatandaşlık, anne, çalışan gibi rolleri ve algılanan özellikleri ne olursa olsun kent içerisinde kentsel yoksunluk yaşamadan var olabilmesi önemlidir. Bir kent kadın dostu olmalı ve yalnızca erkek kullanıcılar için değil, kadın kullanıcılar için de planlanmalıdır (Güney vd., 2020).

\section{Kahvehane Kültürü ve Cinsiyet Kavramı}

Tarihin tüm zamanlarında bir araya gelinen, paylaşımlarda bulunulabilen ortam ve mekânlar daima varlığını sürdürmüş̧ür. İnsanların buluşma merkezleri konumunda olan kahvehaneler; siyaset, edebiyat, sanat ve toplumu ilgilendiren diğer tüm konularda oluşumlara öncülük eden, halkın sorunlarının görüşüldüğg̈ toplanma mekânları olarak tanımlanır (Ediz, 2008). Türk kültürü varlığını sürdürdüğü tüm zamanlarda "kahve ve kahvehane" alışkanlığına sahiptir. Kahvehaneler tarihsel olarak kahvenin Osmanlı ülkesine girmesinden itibaren, kahve içilen mekânlar olarak ortaya çıkmıştır. Zamanla değişime uğrayan ve modernlik kavramından nasibini alan kahvehaneler, Osmanlı'da ve sonrasında da Cumhuriyetin kuruluş döneminde yaşanan sosyal ve siyasal değişimde aktif rol oynamıştır. $O$ dönemlerde kahvehaneler, toplumun nabzını tutan yerler haline gelmişlerdir. Kamuoyunun şekillendiği ve genellikle devlete yönelik eleştirilerin kaynağını oluşturan ana merkezlerden biri olarak karşımıza çıkmaktadır. Bu nedenlerden dolayı kahvehaneler devamlı olarak devlet otoriteleri tarafından takip edilerek kontrol altında tutulmuştur. Ayrıca bu mekânlar aracılığıyla Osmanlı dönemi ve sonrasında yaşanan değişimler gözlenebilmiştir (Ediz, 2008). Siyasi sebeplerden ötürü aralıklarla kapatılan ve gidilmesi yasaklanan, kahvehane olarak isimlendirilen mekânlar kıraathaneler olarak da bilinmektedir. Kahvehaneler bu açılardan ele alındığında Türk kültür hayatının önemli bir konusu ve toplumun mekânsal değerlerindendir. Osmanlıdan bu yana mahalle kahvehaneleri toplumun buluşma ve haberleşme mekânları olmuştur (Ediz, 2008). Kahvehanelerin ilk defa ortaya çıkışları göz önüne getirildiğinde toplumun ne amaçla bu kavramı benimsediği anlaşılmaktadır. Osmanlı döneminde ilk kahvehaneler camilerin yanında açılmış̧ır. Namaz vakitleri arasında insanlar kahvehaneleri kullanmış, küçük kulübeler şeklinde olan bu mekânlarda çay içip sohbet etmişlerdir (Aydoğan, 1997). Cami yakınlarında varlığını sürdüren kahvehaneler coğrafya fark etmeksizin işlevlerini Osmanlı'nın dört bir yanında gerçekleştirmiştir.

Türk geleneğinde kahvehaneler yalnızca bir zaman geçirme mekânı olarak değil, sanatsal aktivitelerin de gerçekleştirildiği bir sahne olarak halk edebiyatına hizmet etmek amacıyla kullanılmışken; 20. yüzyılın son çeyreğinden itibaren bu özelliklerini kaybetmişlerdir. Günümüzde ise yalnızca çay, kahve içilen ve sohbet edilen ayrıca çeşitli şans oyunlarının oynandığı mekânlar olarak kullanılmaktadır. Bu açıdan incelendiğinde kahvehaneler geleneğin ve sanatın var olduğu alanlar değil boş vakit geçirme alanı konumuna dönüşmüştür. Yeni kuşak olarak değerlendirilen yaş grubunun hafızasında da kahvehaneler bu şekliyle yer almaktadır (Durmaz, 2020).

Kahvehanelerin kentliler tarafından kullanımında çeşitli cinsiyetçi yaklaşımlar bulunmaktadır. Kentsel mekânların bir parçası olan kahvehaneler genellikle erkeklerin kullandığı mekânlardır. Bu mekânlara kadın olarak girmenin mahremiyet kavramına ters olarak algılanması toplumdaki cinsiyetçi ayrışmaların görünen bir şeklidir. Erkeklerin diğer erkeklerle etkileşim içinde olduğu ve erkek homososyalliğini (aynı cinsiyettekiler arasındaki sosyal bağları) oluşturan mekânlar kahvehanelerdir (Sancar, 2013). Bu mekânlar ilk kullanımlarından bu yana 'erkekler evi' ' olarak görülmüş ve kadınlar bu mekânların kapsamında görülmemişlerdir. Kahvehanelerin temel özelliği yalnızca erkeklere özgü olmasıdır. Kadınların bu mekânlardaki varlı̆̆ı kahvehane tanımını imkânsız kılmakta ve kadın ile erkeğin aynı mekânda olması durumunda mekânın bir kahvehane değil de kafe olduğu düşüncesi doğmaktadır (Arık, 2009). Toplumsal yapılaşmada erkeklerin erkek arkadaşlarıyla sosyal bir ortam kurmak amacıyla kahvehanelere gitmesi normal olarak değerlendirilmektedir. Kadınların kahvehaneleri kullanmamasının başında toplumun ürettiği "ayıp" kavramı bulunmaktadır. Bu yaklaşıma göre kadınların kahvehaneye gitmesi anormalleştirilmektedir (Özkök, 2019).

Erzurum kentinde de kıraathane ve kahvehane kültürü Osmanlı'dan beri varlığını sürdürmektedir. Erzurum'da altıyedi ay süren uzun kış mevsiminde dışarıda vakit geçirilecek kentsel mekânlar bulunmaması nedeniyle, Erzurum'da yaşayan erkekler kahvehaneleri doldurmaya adeta mecbur kalmıştır (Aktürk, 2012). Çalışma alanı olarak belirlenen Muratpaşa Cami ve çevresinde de kahvehane kültürü ve mekânsal olarak kapladığı alan geçmiş dönemlerden beri

Evaluation of Women's Behaviours in Urban Public Spaces in terms of Security: the Sample of Muratpaşa Neighbourhood, Erzurum

Journal of Urban Academy | Volume: 14 Issue: 3 | ISSN: 2146-9229

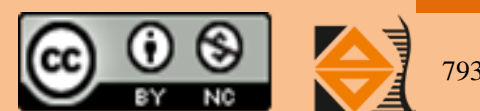


varlığını sürdürmektedir. Bu alanda yapısal olarak tarihi değeri olan kahvehanelerin yanında bu bağlamda bir tarihsel nitelik taşımayan kahvehaneler de bulunmaktadır.

\section{ALAN ÇALIŞMASI, AMACI VE YÖNTEMI:}

$\mathrm{Bu}$ çalışma Erzurum kent merkezi Yakutiye İlçesinde bulunan Muratpaşa Mahallesinde yapıllmıştır. Erzurum Türkiye'nin kuzey doğusunda Doğu Anadolu Bölgesi'nde (39 57' 23" K; 41 $\left.{ }^{\circ} 10^{\prime} 12^{\prime \prime} \mathrm{D}\right) 1758$ - $2100 \mathrm{~m}$ rakımları arasında bulunmaktadır (Şekil 1.) . İl büyükşehir olması nedeniyle nüfusunun tamamı kentli olup 767.848 kişidir. Muratpaşa Mahallesinin toplam nüfusu ise 12.644 kişidir. Mahallede yaşayan kadın sayısı 6.666 iken erkek sayısı ise 5.978'dir (TÜİK, 2018).

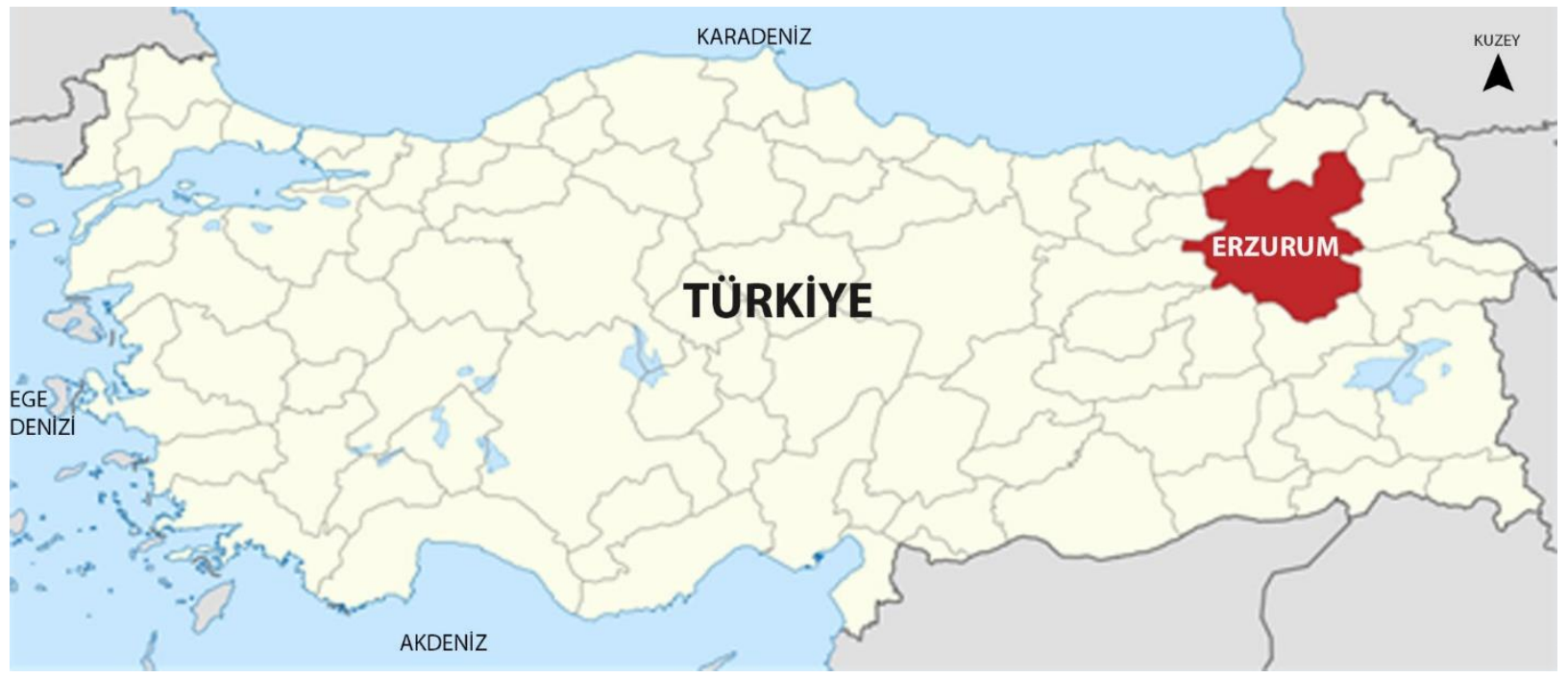

Şekil 1. Erzurum kentinin konumu

Erzurum Kalesi'nin dışında kurulan Muratpaşa Mahallesinin çalışma alanı olarak seçilmesinin nedeni alanın kimlik olarak Erzurum kentinin tarihini ve mevcut toplumsal yapısını yansıtmasıdır. Bunun yanında Muratpaşa Mahallesinin kentin merkez ilçesinde yer alması ve kadın nüfus yoğunluğuna sahip olması da alan seçimi yapılırken önemli etkenler olmuştur. Mahallenin en yoğun yerleşim bölgesi olarak seçilen çalışma alanı Şekil 2.' de gösterilmiştir.

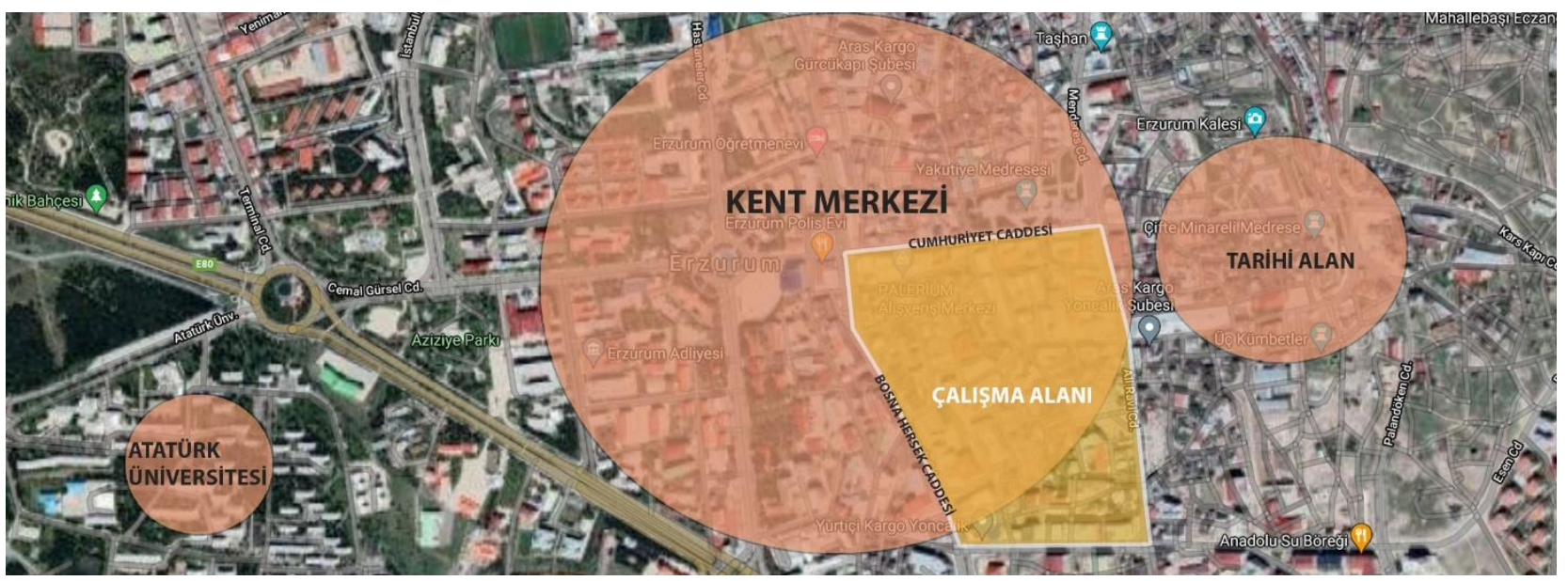

Şekil 2. Çalışma alanının kentteki konumu (Google Haritalar, 2019)

Evaluation of Women's Behaviours in Urban Public Spaces in terms of Security: the Sample of Muratpaşa Neighbourhood, Erzurum

Journal of Urban Academy | Volume: 14 Issue: 3 | ISSN: 2146-9229

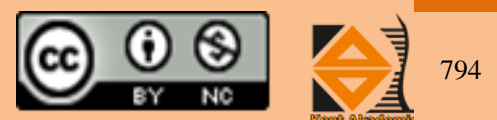


Mahalledeki tarihi niteliğin yanında halkın kimliği de araştırma konusu için büyük önem taşımaktadır. Kadınların geçmiş zamanlara oranla geleneksel yapıdan sıyrılması ve kamusal mekâna karışması son dönemlerde göz ardı edilemeyecek düzeyde artmıştır. Kamusal mekânı kullanmaya ve yönetmeye başlayan kadınlar için en küçük birim olan mahallelerden başlayan sosyal ortamlar ve kültürel düzeyler her dönemde toplum yapısını şekillendirmektedir. $\mathrm{Bu}$ şekillendirme süreci işlerken kentli kadınlar için önem taşıyan güvenlik konusu son dönemlerde sık sık gündeme gelmektedir.

Çalışma kapsamında kadın kullanıcıların kent yaşamında sahip oldukları güvenli olma veya güvensiz olma hislerinin objektif şekilde okunabilmesi amacıyla belirlenen çalışma alanında çeşitli analiz ve anket çalışmaları yürütülmüştür. Analiz çalışmalarının gözlem yapma ve sayım yapma yöntemleriyle elde edilen sonuçları, mahalle halkının kadın ve güvenlik konusunda yaşadığı durumlar hakkında önemli bilgiler verecektir. Anket çalışmasıyla ulaşılan sonuçlar ve anket katılımcıları ile yapılan görüşmelerle de güvenlik hissinin eksikliği ve özellikle kadınların yaşadığı cinsiyet odaklı problemler açığa çıkacaktır.

\section{Toplanma Alanları Analizi}

Muratpaşa Mahallesinin tarihi çekirdeğe çok yakın olması ve gündelik yaşamda Erzurum kentinin merkez noktasını oluşturması toplanma alanları analizinin yapılmasını gerekli kılmaktadır. Alandaki odak noktaların belirlenmesi, çalışmayı yürütürken mahallenin kimliğinin daha iyi anlaşılmasını sağlayacaktır. Çalışma alanında odak olarak görülen mekânlar önem derecelerine göre analiz edilmiştir. Söz konusu olan önem derecesi belirlenirken, tarihi nitelik ve halkın kullanım yoğunluğu esas alınmıştır. Çalışma alanında belirlenen odak noktaları Şekil 3.' te görülmektedir. Birincil odak, ikincil odak ve üçüncül odak olarak derecelendirme yapılması analizin okunurluğunu sağlamaktadır. Tarihi alan olarak nitelendirilen Erzurum Kalesi ve Çifte Minareli Medrese aksı uzantısında yer alan Cumhuriyet Caddesi şehrin ticari ve sosyal mekânlar anlamında kalbi niteliğindedir. Merkezi iş alanı yoğunluğuna sahip bölgede ticari kullanım yoğunluğunu oldukça fazladır. Yakutiye Medresesi ve Lalapaşa Cami de Cumhuriyet Caddesi üzerinde yer almakta olup mekânın tarihi niteliğini artırmaktadır. Muratpaşa Mahallesinin tarihi, sosyal ve ticari anlamda bu kadar nitelikli bir bölgede yer alması yerleşim açısından cazibe noktası oluşturmaktadır.

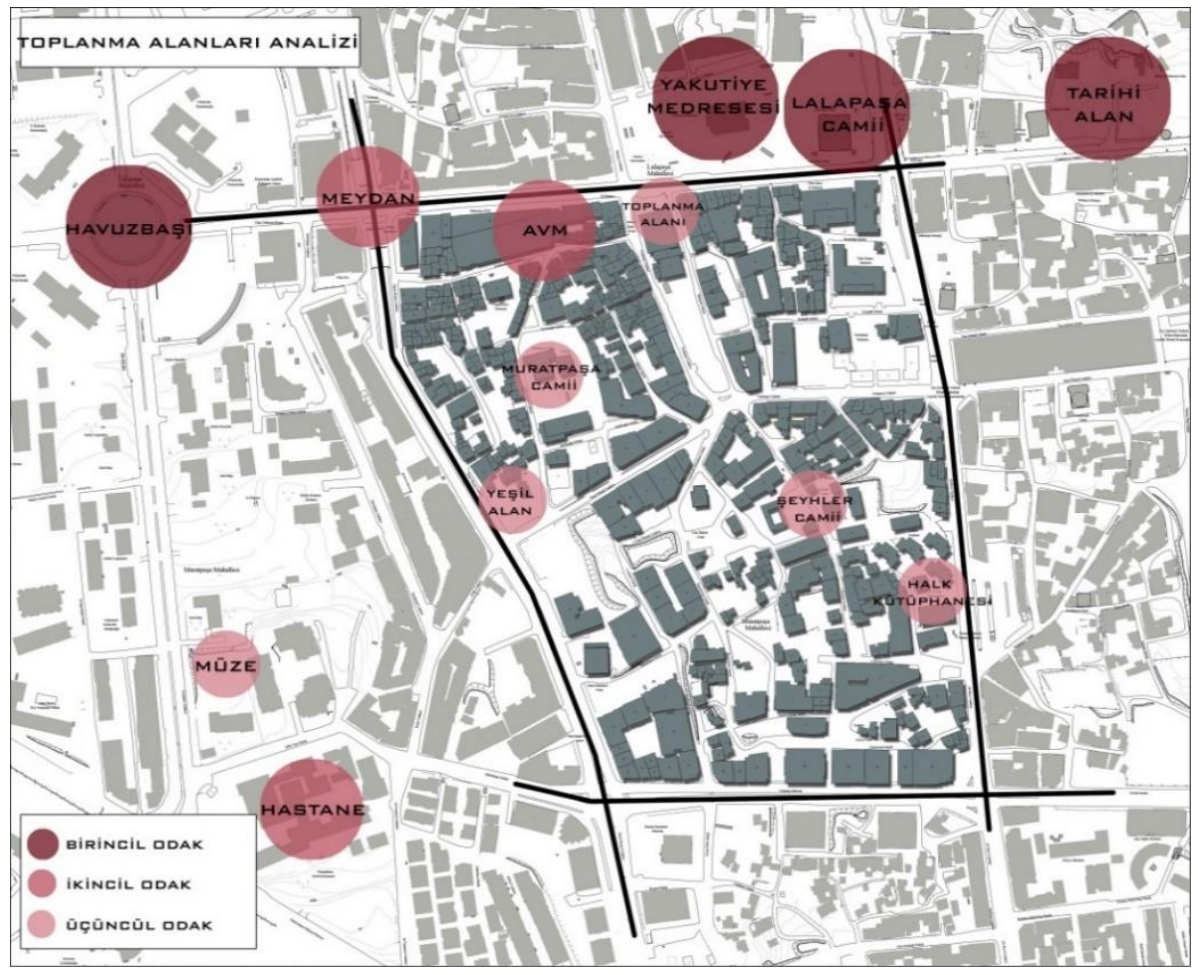

Şekil 3. Toplanma alanları analizi

Evaluation of Women's Behaviours in Urban Public Spaces in terms of Security: the Sample of Muratpaşa Neighbourhood, Erzurum

Journal of Urban Academy | Volume: 14 Issue: 3 | ISSN: 2146-9229

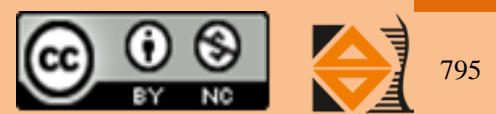




\section{Kahvehane Yoğunluk Analizi}

Çalışma alanında yer alan kahvehanelerin konumlarının belirlenerek analiz edilmesi çalışmanın asıl sorusu için bir altlık oluşturacaktır. Böyle bir analiz ile çalıșma alanı içerisindeki kahvehanelerin konumlarına göre kadın kullanıcıların kentsel mekânı kullanımı konusunda yapılacak çıkarımlar çalışmanın nesnellik düzeyini artıracaktır. Şekil 4.'te alandaki kahvehane (kıraathane, çay evi) konumlarına yönelik yapılan analiz görülmektedir. Mavi renkli noktalama gösterimleri çalışma alanındaki kahvehanelerin konumunu göstermektedir. Analiz sonucunda alanın belirli bir bölümünde kahvehane yoğunluğu olduğu görülmektedir.

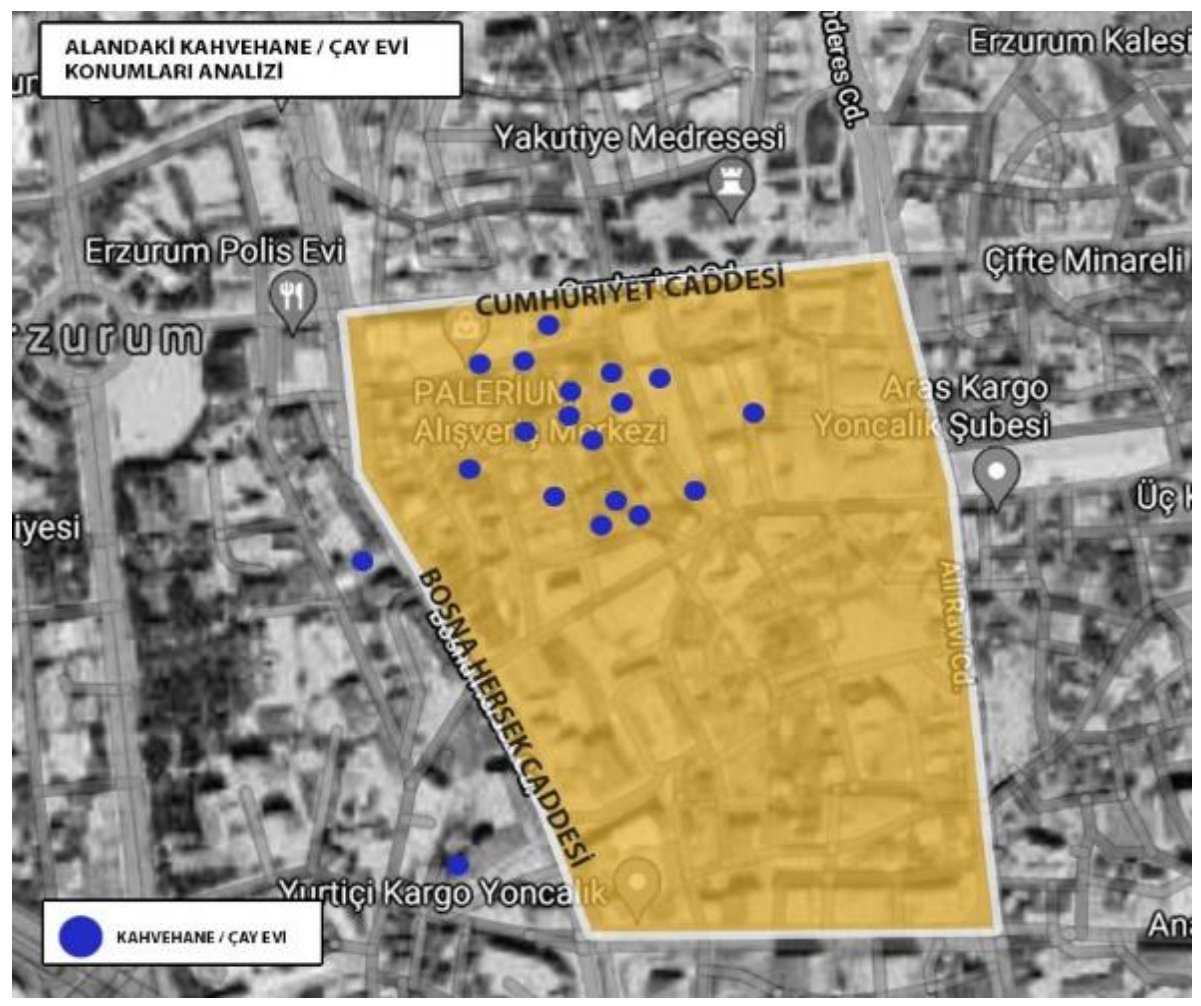

Şekil 4. Alandaki kahvehane /çay evi konumları analizi

\section{Kullanııı Davranışı Analizi}

Muratpaşa Mahallesinin nüfus verileri incelenerek 2019 y1lında 12.644 olan toplam nüfus içinde kadın nüfusunun erkek nüfusundan \%5,4 oranında daha fazla olduğu görülmüştür. (TÜiK, 2019) Şekil 5.' te Muratpaşa mahallesine ait genel bilgiler yer alırken Şekil 6.' da ise nüfusun yıllara ve cinsiyete göre dağıllım grafikleri görülmektedir.

\begin{tabular}{|l|l|}
\hline BAĞLI OLUNAN ILL ADI & ERZURUM \\
\hline BAĞLI OLUNAN ILLÇE ADI & YAKUTIYE \\
\hline BAĞLI OLUNAN BELEDIYE ADI & YAKUTIYE \\
\hline BAĞLI OLUNAN BELEDIYENIN NITELIIĞi & BÜYÜKŞEHIR ILÇE \\
\hline
\end{tabular}

Evaluation of Women's Behaviours in Urban Public Spaces in terms of Security: the Sample of Muratpaşa Neighbourhood, Erzurum

Journal of Urban Academy | Volume: 14 Issue: 3 | ISSN: 2146-9229

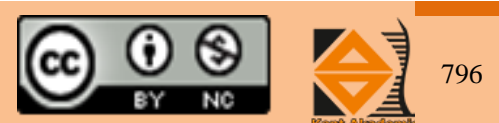




\begin{tabular}{|l|l|}
\hline TOPLAM NÜFUSU & 12.644 \\
\hline KADIN NÜFUSU & 6.666 \\
\hline ERKEK NÜFUSU & 5.978 \\
\hline
\end{tabular}

Şekil 5. Muratpaşa Mahallesi genel bilgileri (TUIK 2019’a göre düzenlenmiş)

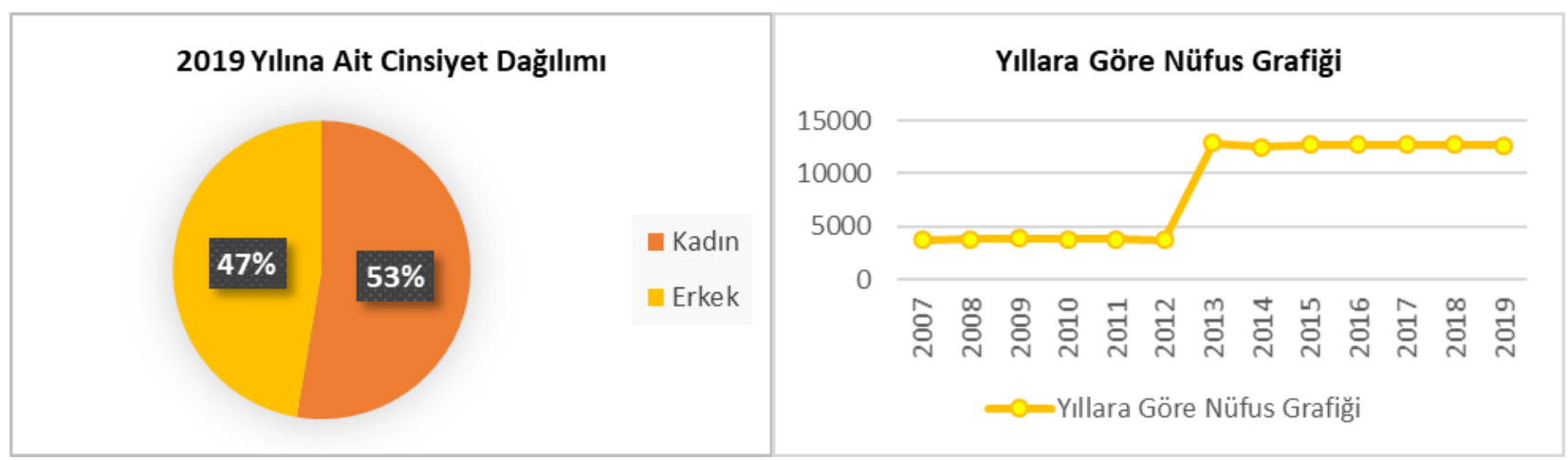

Şekil 6. Muratpaşa Mahallesi nüfus bilgilerine ait grafikler (TÜİK 2019’a göre düzenlenmiş)

6.666 kadının yaşadığı mahallede kadın kullanıcıların davranışlarının mahallenin genel yapısını önemli ölçüde etkilemesi nedeniyle 'kullanıcı davranışı analizi" yapılması gerekli görülmüştür. Kentli kadınların kentin en küçük yapıları olan mahallelerdeki davranışları ile toplumsal gelişim veya değişim sağlanması kaçınılmaz bir gerçektir. Kullanıcı davranışı analizi ile kullanım yoğunluğu, kullanım saati ve kullanılan rotalar kadınların mahalledeki rolü hakkında çıkarımlarda bulunulmasına yardımcı olacaktır. Kullanıcı davranışı analizi yapılırken temel olarak kadın ve erkek kullanıcıların mahalle içindeki hareketlerinin gözlenmesi esas alınmıştır. Bu yöntem ile mahalle halkının hangi noktaları yoğun olarak kullandığı tespit edilecektir. Yapılan tespitler mahalledeki güvenlik konusunda doğru çıarımlar sunacaktır.

Analiz hafta içi bir gün ve hafta sonu bir gün, sabah ve akşam saatlerinde belirlenen noktalardan geçen kullanıcı sayısının belirlenmesine yönelik yapılan sayımlarla yürütülmüştür. Sayımlar toplamda 4 gün belirlenen saat aralıklarında gerçekleştirilmiştir. Sayım yapılacak gün ve saatler; 17 Mart 2019 Pazar günü saat 11.00-13.00 ve 20.0022.00 arası, 18 Mart 2019 Pazartesi günü saat $11.00-13.00$ ve saat 20.00-22.00 arası olarak belirlenmiştir. Analiz çalışmasının hafta içi ve hafta sonu olarak ikiye ayrılarak yürütülmesinin sebebi; günlük kullanım farklılığını ön plana çıkarmaktır. Kullanım farklılı̆̆ı çalışma alanının merkezi konumda olmasıyla da daha net algılanacaktır. Ayrıca gün ortası diyebileceğimiz saat 11.00-13.00 arasında (insan yoğunluğun en yüksek olduğu zaman diliminde) sayım yapılması mekânın en yoğun kullanımını göstermiştir. Akşam saatlerinde (20.00-22.00) bir sayım yapılması da gece kullanım oranını göstermiş ve mahalledeki güvenlik hissi konusunda tutarlı bulgular elde edilmesini sağlamıştır.

Ana caddeler ve ara sokaklarda belirlenen gün ve saat aralığında geçen kadın ve erkek kullanıcılar yoğunluklarına göre Şekil 7., Şekil 8., Şekil 9. ve Şekil 10. 'da sembolize edilmiştir. Kırmızı renkli olarak gösterilen noktalar o bölgeden geçen kadın kullanıcıların yoğunluğunu temsil ederken, mavi renk ile gösterilen noktalar ise erkek kullanıcıların yoğunluğunu temsil etmektedir. 


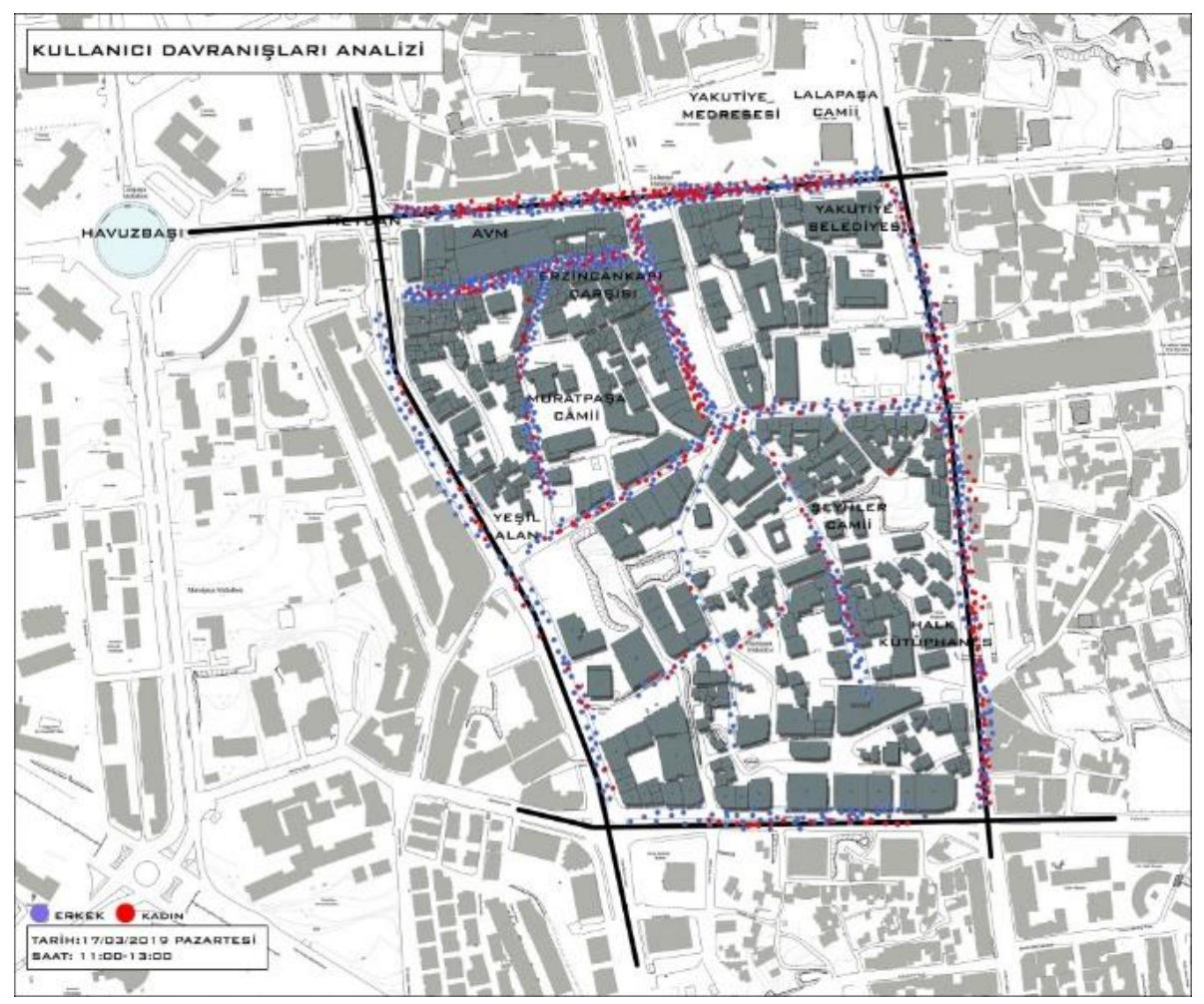

Şekil 7. 18 Mart 2019 Pazartesi (11.00-13.00)

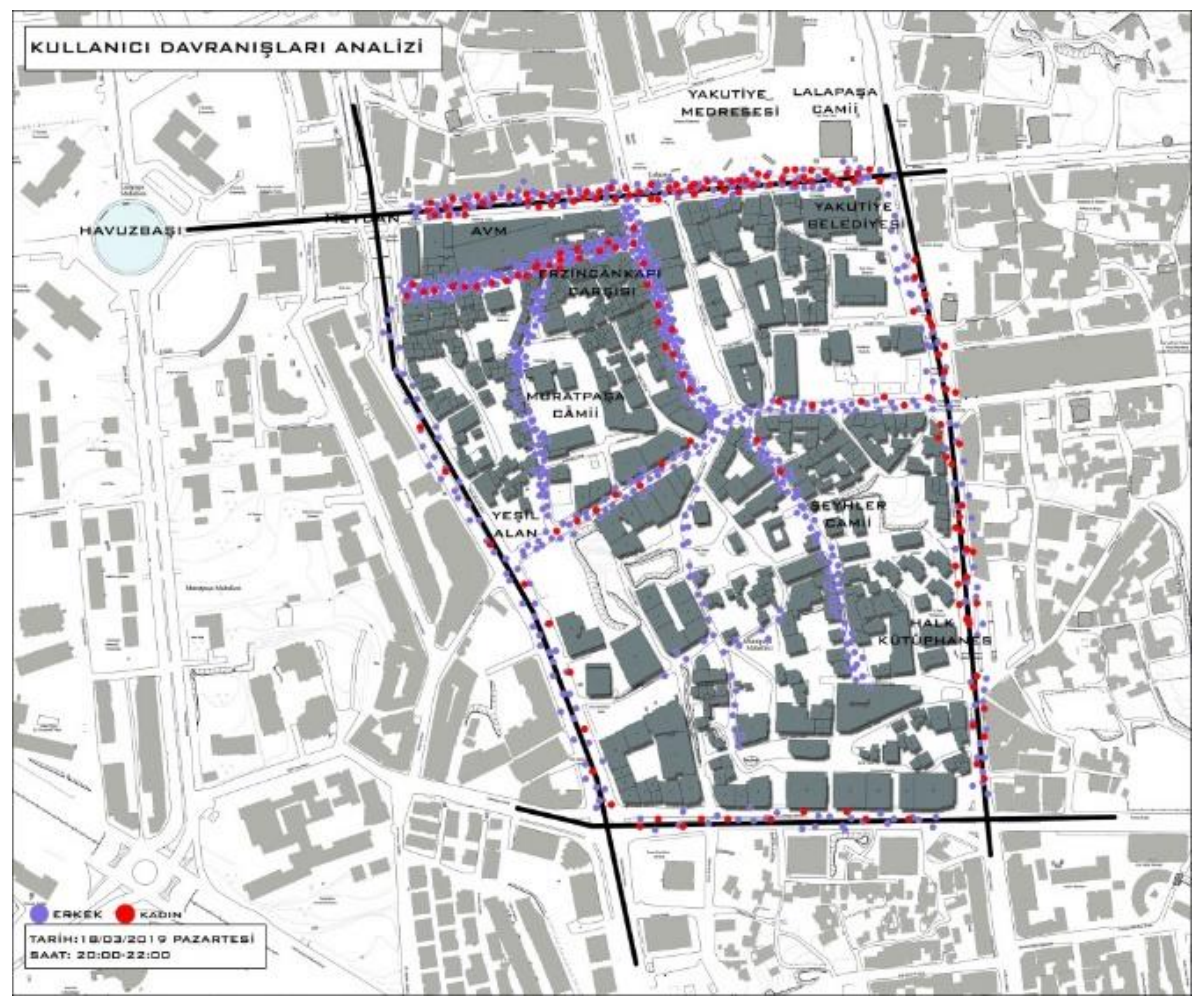

Şekil 8. 18 Mart 2019 Pazartesi (20.00-22.00)

Evaluation of Women's Behaviours in Urban Public Spaces in terms of Security: the Sample of Muratpaşa Neighbourhood, Erzurum

Journal of Urban Academy | Volume: 14 Issue: 3 | ISSN: 2146-9229 


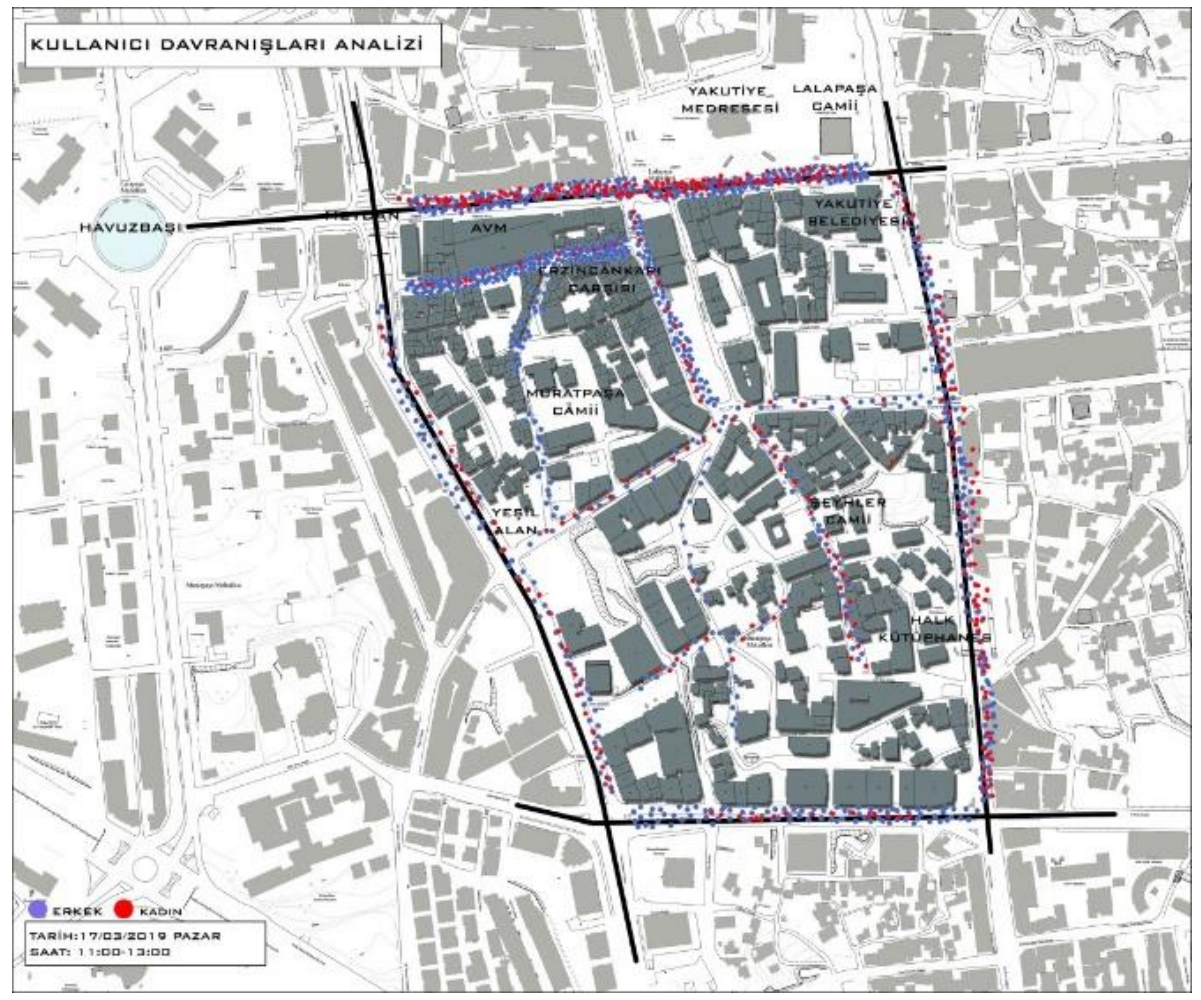

Şekil 9. 17 Mart 2019 Pazar (11.00-13.00)

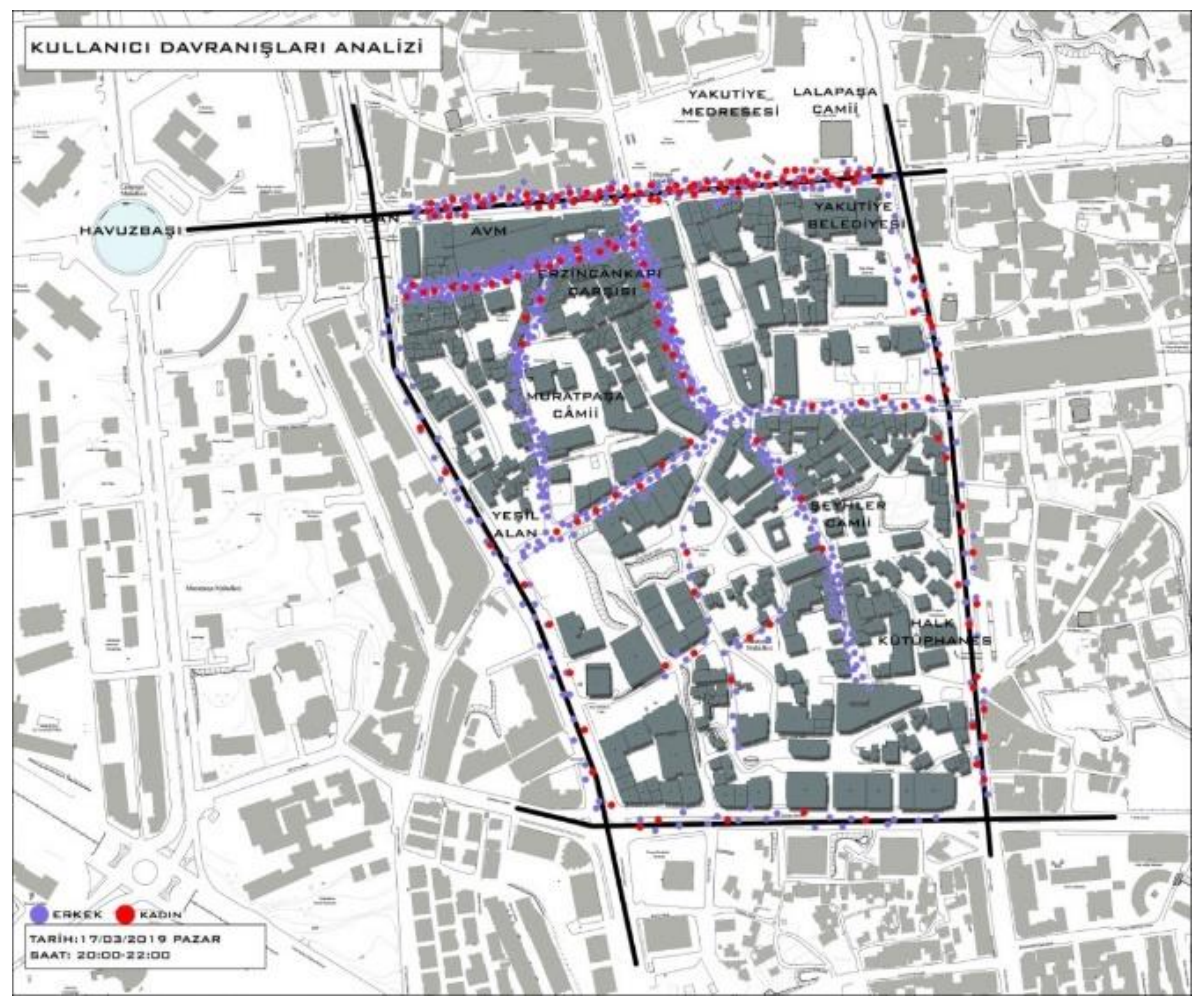

Şekil 10. 17 Mart 2019 Pazar (20.00-22.00)

Evaluation of Women's Behaviours in Urban Public Spaces in terms of Security: the Sample of Muratpaşa Neighbourhood, Erzurum

Journal of Urban Academy | Volume: 14 Issue: 3 | ISSN: 2146-9229 
Ana caddelerin genelinin yoğun kadın ve erkek kullanıcı geçişine sahip olması normal görülen bir durumdur. Ancak bunun yanında bazı ara sokaklardaki kullanım yoğunluğunda ciddi dengesizlikler görülmektedir. Ana caddelerde kadın kullanıcıların erkek kullanıcılar ile yakın seviyelerdeki kullanım yoğunluğu mevcut iken ara sokaklara girildikçe bu yoğunluk farkı artmakta ve bazı noktalarda sıfır seviyesinde kadar düşmektedir. Çalışma alanı olarak seçilen bölgenin özellikle bir yerleşim bölgesi olması, kentli kadınların yaşam alanlarını kullanabilme seviyelerini görebilmek için önem taşımaktadır. Yürütülen analizlerde ara sokak kullanımının ciddi seviyelerde düşük olması mahallenin büyük güvenlik sorunlarına sahip olduğu kanısını doğrular niteliktedir. Gündüz saatlerinde yapılan sayım çalışmalarında ara sokaklarda kadın kullanıcıların az yoğunlukla olsa da varlığı görülürken, akşam saatlerindeki sayım çalışmalarında kadınların hiç geçmediği sokaklar olduğu görülmüşsür (Şekil 11, Şekil 12 ve Şekil 13). Bu durum kadınların gece sokağa çıkmasının bir yasak gibi algılandığı toplumsal baskıları akla getirmektedir. Erkeklerin sokağı günün her vakti özgürce kullanabildiği ve onlara ait olan bir ortam olarak görmeleri kaçınılmaz bir gerçektir. Bunun yanında kadın için ise sokak, genellikle sözlü ya da fiziksel tacize uğrayabildiği bir mekân durumundadır. Yapılan analizler güvenlik hissi konusunda ciddi eksikliklerin olduğunu göstermektedir. Ayrıca kadın kullanıcılar tarafindan hiç kullanılmayan sokak ve caddelerin var olması da o caddeler üzerinde bulunan fonksiyonların (dükkân, ev, kahvehane vb.) incelenmesi gerekliliğini ortaya çıkarmaktadır.

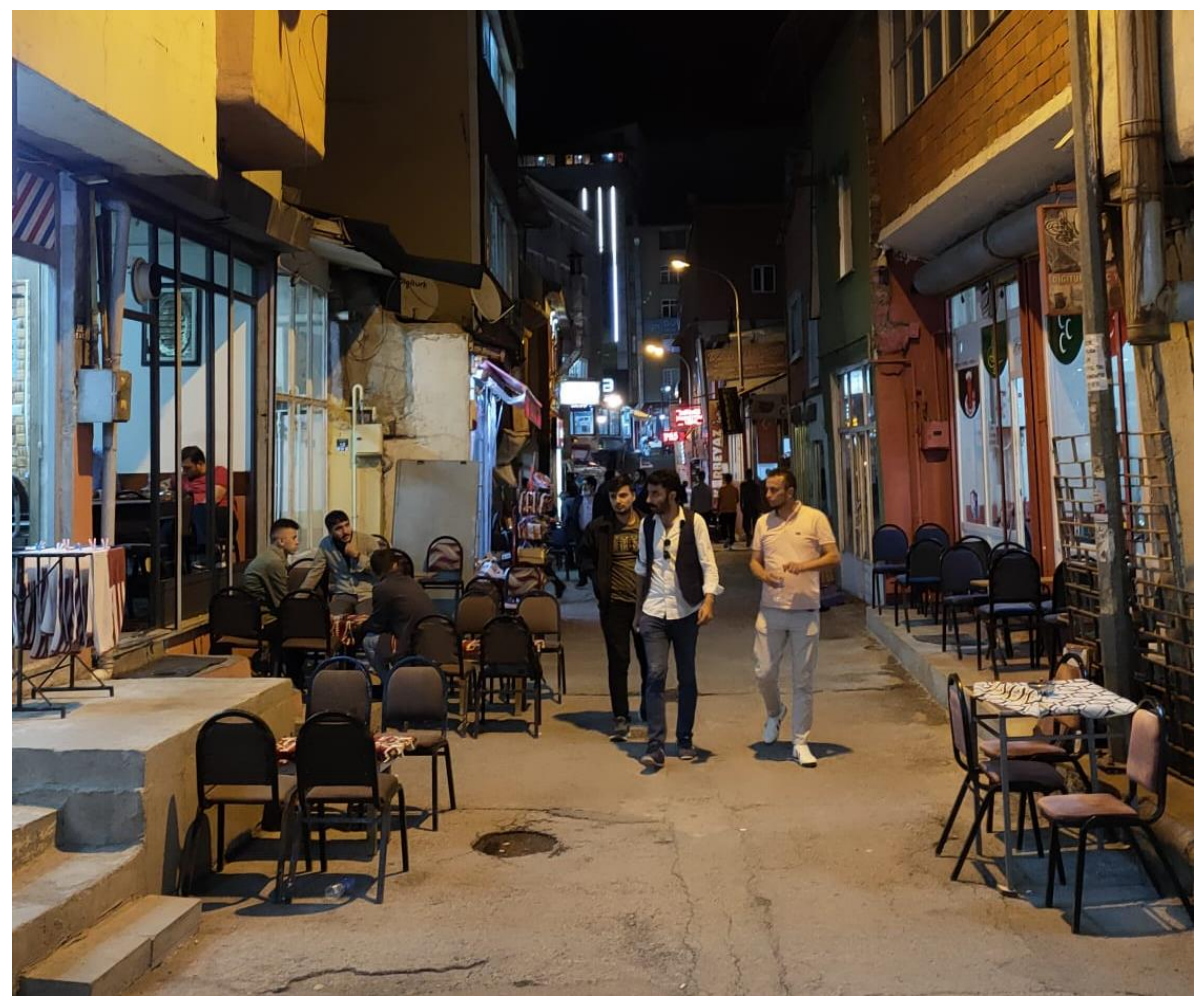

Şekil 11. Çalışma alanında yoğunlaşmış kahvehaneler ve erkek kullanıcılar 


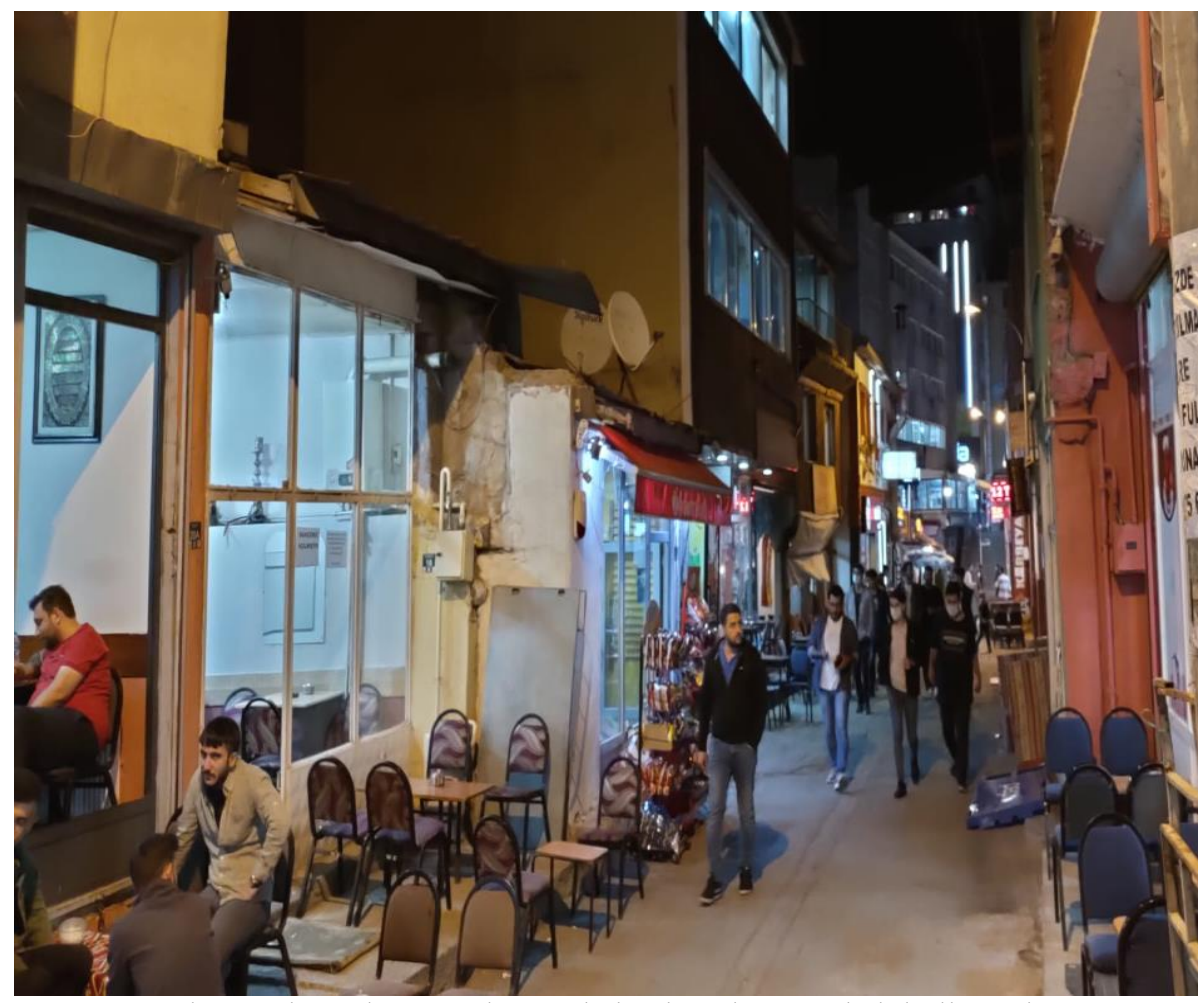

Şekil 12. Çalışma alanında yoğunlaşmış kahvehaneler ve erkek kullanıcılar

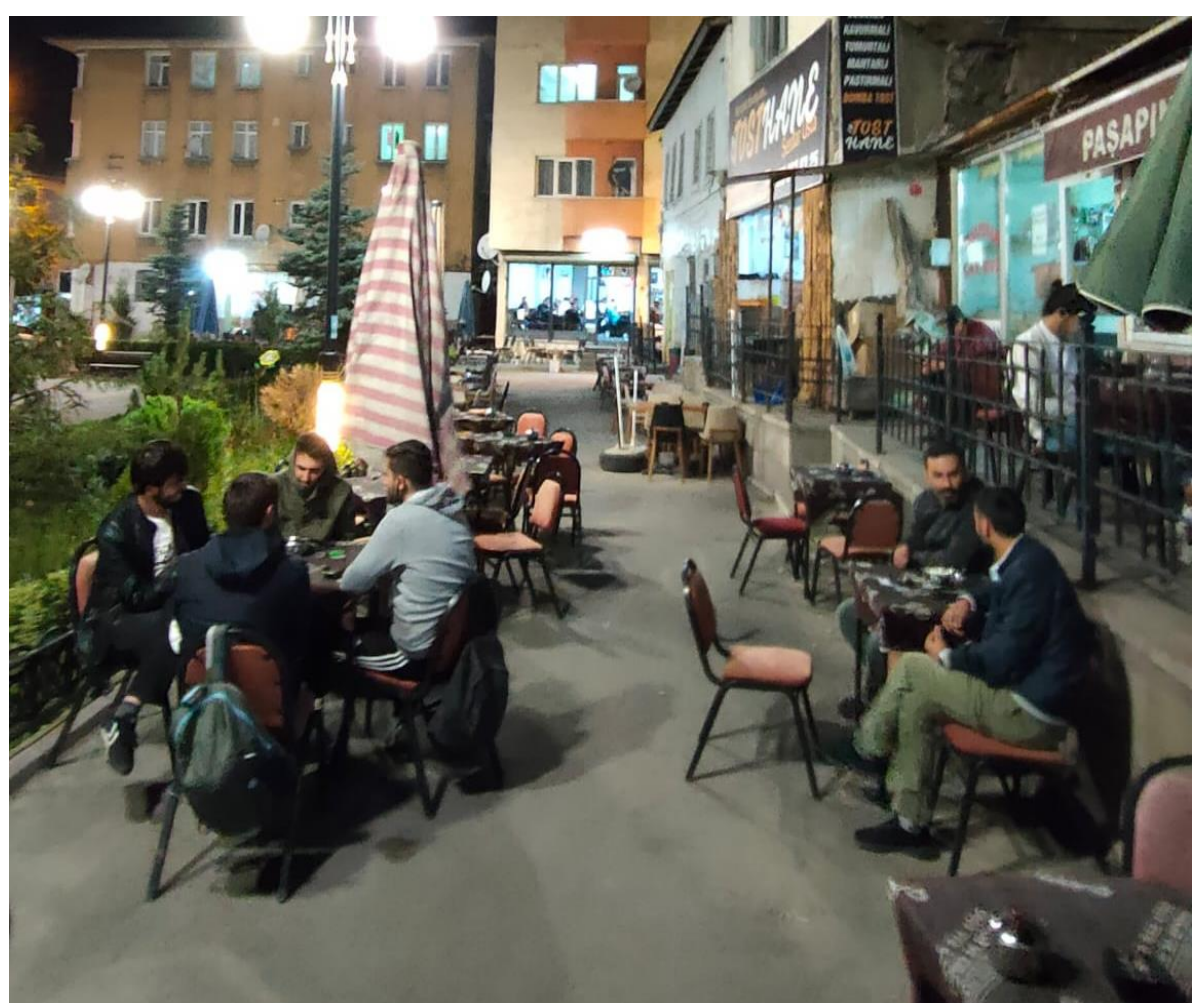

Şekil 13. Çalışma alanında yoğunlaşmış kahvehaneler ve erkek kullanıcılar

Evaluation of Women's Behaviours in Urban Public Spaces in terms of Security: the Sample of Muratpaşa Neighbourhood, Erzurum

Journal of Urban Academy | Volume: 14 Issue: 3 | ISSN: 2146-9229

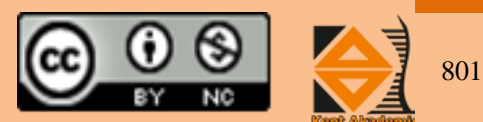


Tarihi bir bölge olan Muratpaşa Cami'nin ve Erzincankapı çarşısının bulunduğu bölgede özellikle Erzincankapı Sokağ1 ve Muratpaşa Caddesi kadın kullanıcıların hiç kullanmadığı noktalar olarak belirlenmiştir. Muratpaşa Caddesinde 17 Mart 2019 Pazar günü saat 11.00-13.00 ve yine aynı gün saat 20.00-22.00 arasında yapılan sayımda caddeyi kullanan kadın sayısı sıfır seviyesine yakındır. Ayrıca 18 Mart 2019 Pazartesi günü saat 20.00-22.00 arasında yapılan sayımda da Muratpaşa Caddesini kullanan kadın kullanıcı sayısı sıfır olarak belirlenmiştir. Kullanıcı sayısının sıfır olarak belirlendiği 18 Mart 2019 Pazartesi günü 20.00-22.00 arası yapılan sayımın akşam saati olması güvenlik konusunu tekrar gündeme getirmektedir. Kadınların aynı gün aynı akşam saatlerinde çalışma alanı içinde diğer sokakları kullanıyor iken Muratpaşa Caddesini kullanmıyor olması dikkat çekicidir. Bu durum mahallenin genel yapısını etkilemektedir. Muratpaşa Caddesinin kullanılmıyor oluşunun sebeplerine bakıldığında bölgede karşımıza çıkan ve sayıca yoğun olan kahvehaneler, kıraathaneler ve oyun salonları bölgenin durumu konusunda çıkarım yapılmasını sağlamaktadır. Cinsiyetçi ayrışmanın hakim olduğu kentsel mekanlardan biri olarak sayılabilecek bu alanda, kahvehanelerde cinsiyetçi ayrışmanın en net hali okunmaktadır. Kahvehanelerin cinsiyete göre kullanım yoğunluğuna etkisinin daha objektif verilerle görülmesi için mahalle halkıyla bir anket çalışması da yapılmıştır. Anket çalışması yapılmadan önce bölgedeki aydınlatma elemanları ve sokak lambalarının güncel durumu analiz edilerek güvenlik sorununun kaynaklarından olabilecek ışıklandırma konusu da ayrıca ele alınmıştır.

\section{Gece Işıklandırma Analizi}

Kullanıcı davranışı analizi ile yapılan sayımlardan sonra kadın kullanıcıların kullanım yoğunluğunun akşam saatlerinde az olması nedeniyle gece ışıklandırması seviyesini belirlemek amacıyla bir analiz yapılmıştır. Gece 1şıklandırma analizi, Muratpaşa Mahallesi kentsel mekânının kullanım yoğunluğunun az olmasının sebeplerini açığa çıkarmaya yardımcı olacaktır.

Çalışma alanı olarak belirlenen alandaki tüm sokaklar 18 Mart Pazartesi günü saat 20.00 - 22.00 arasında dolaşılarak mevcut aydınlatma oranları incelenmiştir. Işıklandırmanın yeterli ve yetersiz olduğu alanlar tespit edilmiştir. Aydınlatma oranları sokak lambaları ve diğer aydınlatma elemanları ile ilişkilendirilmiş ve karanlık sokakların kullanıcıların kullanım oranıyla olan ilişkisi gözlenmiştir. Gece ışıklandırma durumu Şekil 14'te gösterilmiştir.

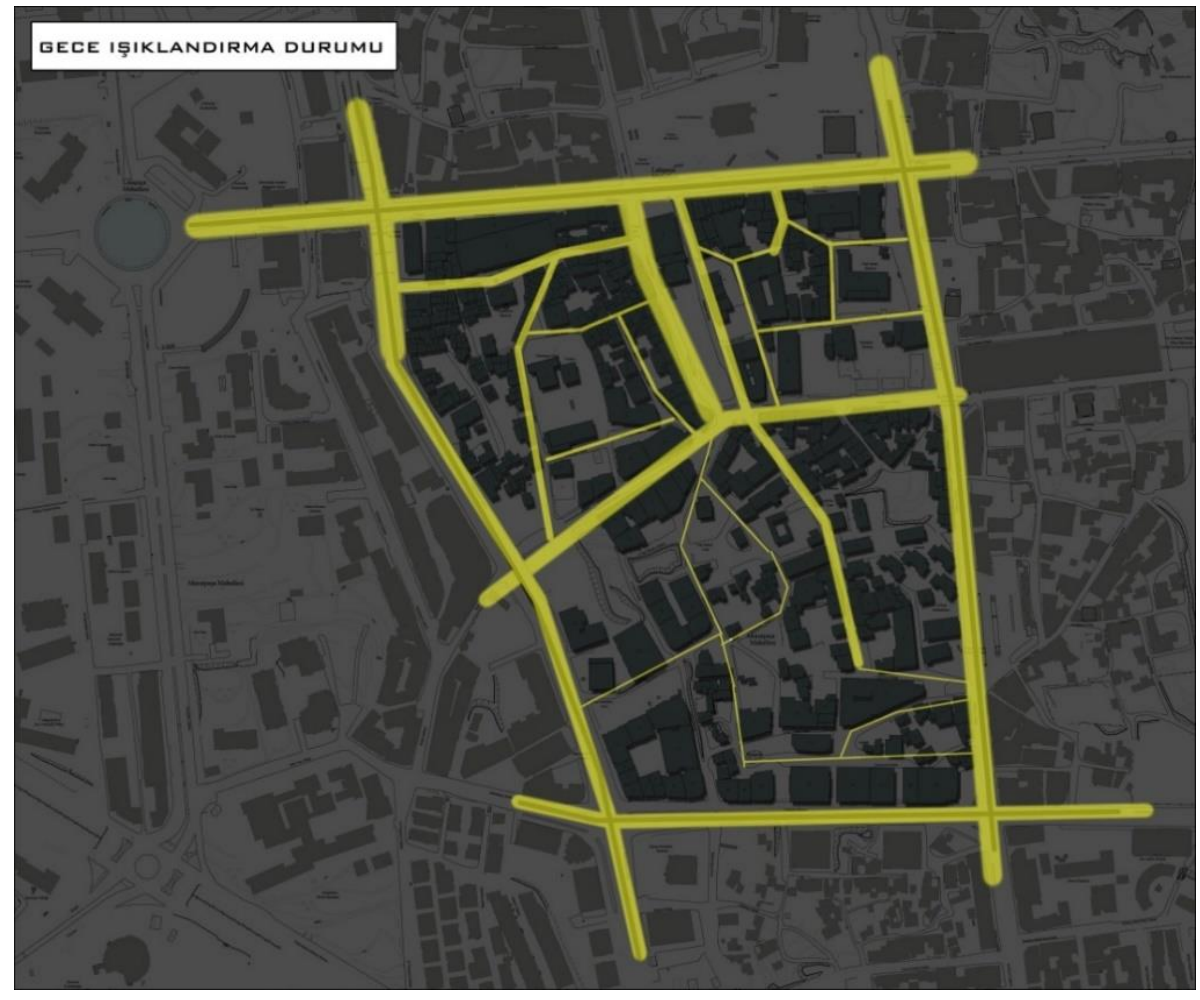

Şekil 14. Gece 1şıklandırma durumu

Evaluation of Women's Behaviours in Urban Public Spaces in terms of Security: the Sample of Muratpaşa Neighbourhood, Erzurum

Journal of Urban Academy | Volume: 14 Issue: 3 | ISSN: 2146-9229

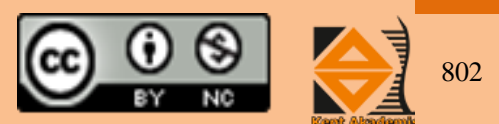


Sarı renk ile ifade edilen aydınlık derecesi ana caddelerde yüksek seviyelerde (yoğun sarı renk gösterimi) iken ara sokaklarda bu seviyelerde azalmalar (düşük sarı renk gösterimi) görülmektedir. Bazı sokaklarda ise sokak lambası ve aydınlatma elemanı sayısının sıfır (karanlık sokaklar) olduğu tespit edilmiştir.

Gece 1şıklandırma analizi, kullanıcı davranışı analizi ve kahvehane yoğunluk analizi ile ilişkilendirilerek kadın kullanıcıların mahalleyi kullanımını objektif biçimde gözlemlemeye destek olmuştur. Karanlık olarak nitelendirebileceğimiz yetersiz aydınlatmaya sahip sokak ve mekânlar, kullanıcı davranışı analizinde de kullanım yoğunluğu düşük bölgelerle örtüşmektedir. Kahvehanelerin yoğun olduğu cadde ve sokaklarla da örtüşen analizler, Erzurum Kenti Yakutiye İlçesi Muratpaşa Mahallesinde belirlenen kentsel mekânlardaki kadın kullanıcıların güvenlik problemlerinin okunmasında net sonuçlara ulaştırmıştır. Yapılan bu analizle aydınlatma seviyesi yetersiz olan alanların kullanım yoğunluğunun düşük olduğu ve paralelinde güvenlik endişesinin ön plana çıktığı açıktır.

\section{Anket Çalışması}

Çalışma alanı olan Muratpaşa Mahallesinde mevcut kentsel mekânın kullanım durumu kadın ve güvenlik kavramları çerçevesinde, yürütülen bir anket çalışması ile geniş kapsamda ele alınmıştır. Kahvehanelerin kentsel mekânların kullanım yoğunluğuna etkisinin detaylı ve objektif şekilde incelenmesi çalışmanın sonuçlarını etkileyecektir. Bu nedenle çalışma alanı olarak belirlenen kentsel mekânda yaşayan mahalle halkı ile bir anket çalışması yapılmıştır. Muratpaşa Mahallesinde yaşamakta olan 53 kişiye yöneltilen sorular ile gerçekleştirilen anket çalışması ortaya nitelikli sonuçlar çıkarmıştır. Anket çalışması mahallede yaşayan kişilerin objektif cevaplar verebilmeleri için çevrimiçi ortamda 'Google Formlar'" anket yönetimi uygulaması kullanılarak yapılmıştır. Bu uygulama ile kişilerin verdiği cevaplar pasta grafikleri oluşturularak somutlaştırılmıştır. Kullanıcılara toplam 10 adet soru yöneltilmiştir. Soruların 9'u çoktan seçmeli cevaplar içerirken, 1'i açık uçlu cevap yöntemiyle düzenlenmiştir. Anket mahallede yaşayan kişilerin cinsiyetleri, mahalleyi tercih sebepleri ve mahalle hakkında şikâyetçi oldukları konuların neler olduğuna yönelik sorular içermektedir.

Muratpaşa Mahallesi kentsel mekânı güvenlik analizi anket sorularına \% 66 oranında kadın kullanıcılar , \% 34 oranında ise erkek kullanıcılar yanıt vermiştir (Şekil 15.).

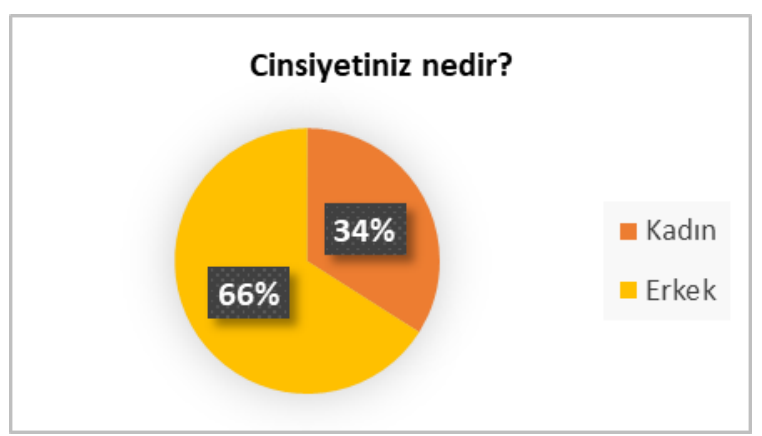

Şekil 15. Cinsiyet dağılım grafiği

Kullanıcıların yaş aralığı çeşitlilik göstermekte olup sonuçlarda çıkan en yüksek oran \% 37,7 ile 25-35 yaş aralığıdır. 45 yaş ve üzeri de en düşük dilime sahip olup \% 9,4 olarak görülmektedir (Şekil 16.). 


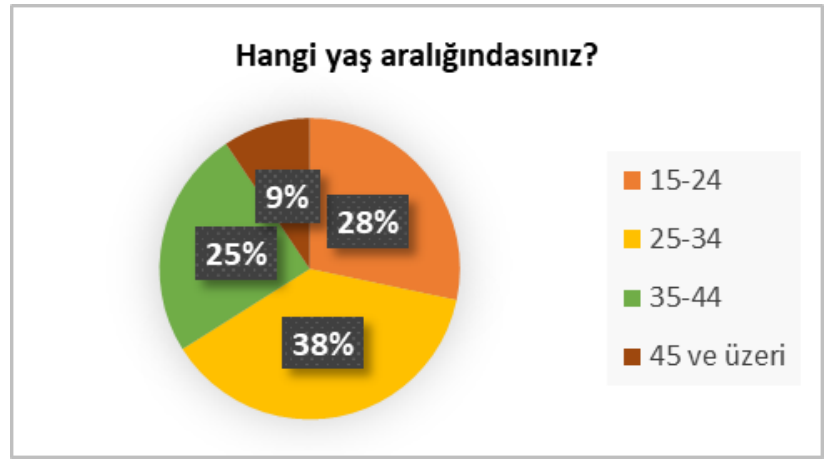

Şekil 16. Yaş aralığı grafiğgi

Muratpaşa Mahallesinde yaşayan kullanıcıların toplumsal kimlik olarak mahalleye hangi süreyle bağlı olduklarını ölçmek amacıyla kaç yıldır bu bölgede oturdukları sorusu yöneltilmiştir. Alınan yanıtlar değişkendir (Şekil 17.). Bu durum mahalledeki toplumsal yapı değişimini olduğu sonucunu doğurmaktadır. \% 39,6 oranı ile 5 yıl ve üzeri sonucunun en büyük dilimi oluşturması oldukça şaşırtıcıdır. Erzurum kentinin en eski yerleşim alanlarından biri olan Muratpaşa Mahallesinde kısa süreli bir oturma durumu görülmesi son dönemlerde farklı bölgelerden göç almaya başladığını kanıtlamaktadır. \% 26,4 oranı ile sonuçlanan 15 yıl ve üzeri süredir oturma oranı ise mahallede eski ve geleneksel kimliği taşıyan bir çoğunluğun da var olduğunu göstermektedir. Bu sonuçlar mahallede yeni yerleşimlerin ve yeni kültürel oluşumların başladığını kanıtlar niteliktedir.

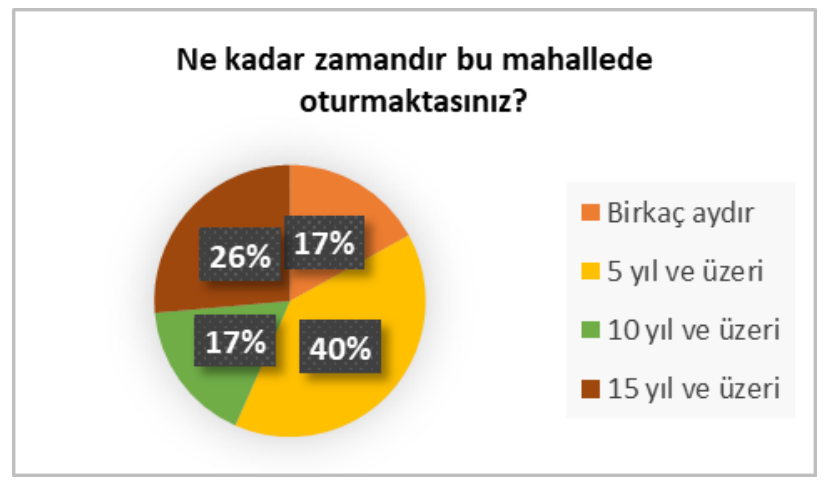

Şekil 17. Mahallede barınma süresini gösteren grafik

Kullanıcılara yaşamak için neden bu mahalleyi tercih ettikleri sorusuna alınan yanıtlardan \% 35,8 oranı ailesiyle birlikte burada yaşayanları göstermektedir. \% 32,1'lik en yüksek ikinci oran ise merkezi konumda olması sebebiyle burada yaşayanların sayısının çokluğunu göstermektedir. Kullanıcıların \% 13,2'si iş yerlerine yakınlığından dolayı bu mahallede yaşadığını belirtirken \% 18,9'luk oran ise açıklamak istemediği diğer sebeplerle bu bölgede oturmayı tercih ettiğini belirtmiş̧ir (Şekil 18.). \% 18,9 oranı göz ardı edilmeyecek seviyede yüksektir ve ne gibi sebepler ile bu bölgede yaşamayı tercih ettikleri konusu merak uyandırmaktadır. 


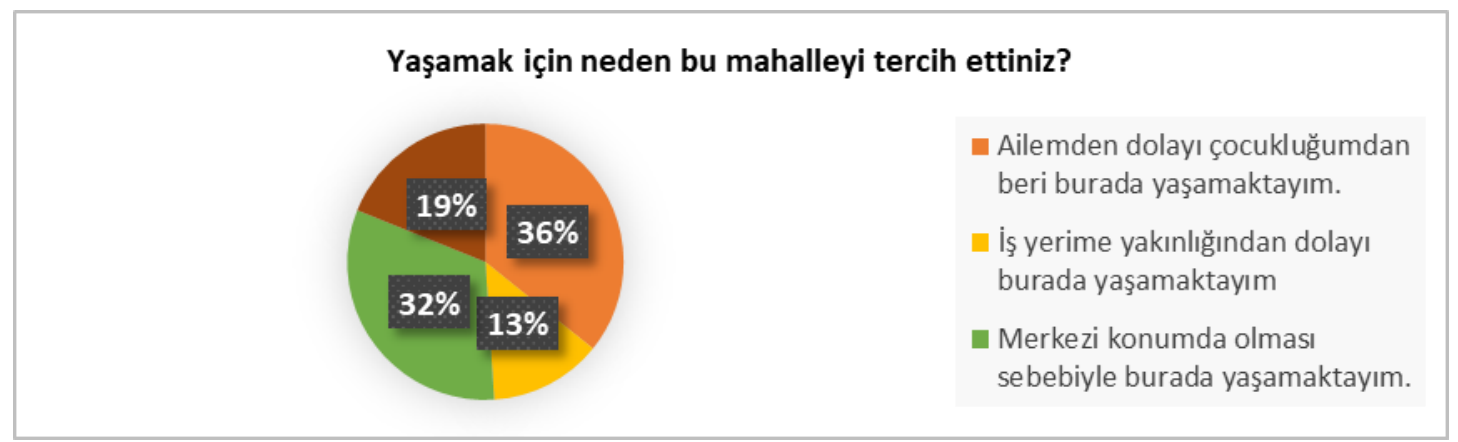

Şekil 18. Mahallenin tercih edilme nedenlerini gösteren grafik

Mahalle halkının evlerinin kendilerine ait olup olmaması da Muratpaşa kentsel mekânının toplumsal yapısı hakkında fikirler vermektedir. \% 44,2 oranı mevcut ev sahiplerini gösterirken, \% 55,8 oranı ise ev sahibi olmayanların yüzdeliğini göstermektedir (Şekil 19.). Bu durumda bölgede yaşayanların kimliğinin modern hayat düzeniyle değişime uğradığı ve eski kültürel yapının aynı kalmadığı sonucuna ulaşılabilir.

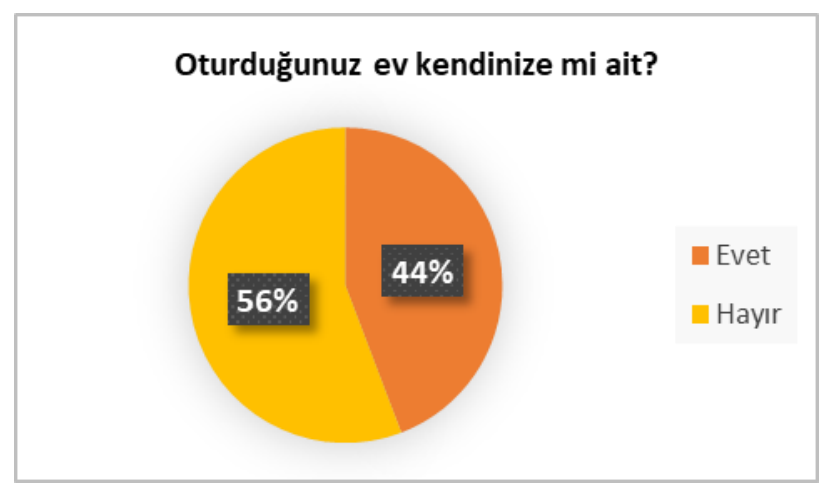

Şekil 19. Mülk aidiyetini gösteren grafik

Kullanıcılara yöneltilen 'Evinize ulaşmak için yürüdüğünüz zaman ana caddeleri mi yoksa ara sokakları mı kullanırsınız?" sorusuna verilen yanıtlar kullanıcı davranışı analizinde ve gece 1şıklandırma analizinde ulaşılan sonuçlar ile paralellik göstermektedir. \% 54,7 oranında verilen "ana caddeleri kullanarak evime ulaşırım" yanıtı ile kullanıcıların ara sokaklara girmeyi daha az tercih ettiği sonucuna ulaşılmıştır. Mahalle halkının verdiği "'ara sokakları ve kestirme yolları tercih ederim"' yanıtı ise \% 45,3 oranındadır (Şekil 20.).

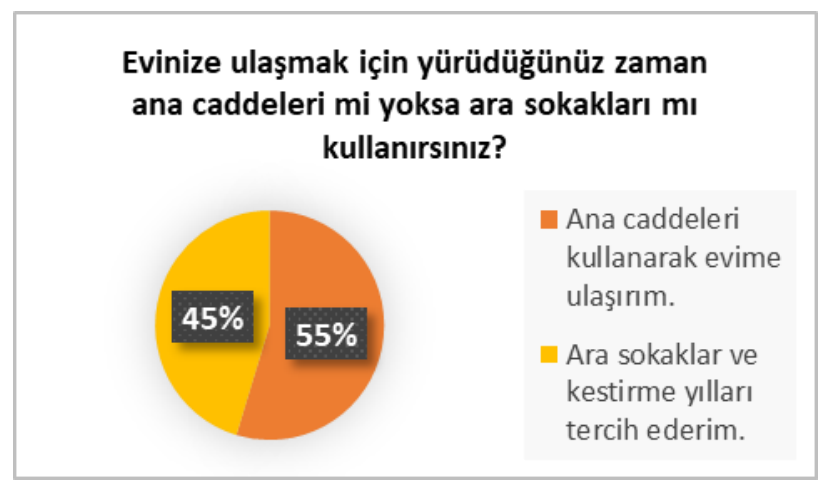

Şekil 20. Ana cadde ve ara sokak kullanımını gösteren grafik

Evaluation of Women's Behaviours in Urban Public Spaces in terms of Security: the Sample of Muratpaşa Neighbourhood, Erzurum

Journal of Urban Academy | Volume: 14 Issue: 3 | ISSN: 2146-9229 
Anket soruları arasında güvenlik konusunda oldukça belirleyici sonuçlar veren 6. Soru çalışma konusu için önem taşımaktadır. Kullanıcı davranışı analizinde ulaşılan ara sokak kullanım azlığı burada da ortaya çıktı̆̆ için kullanıcıları ara sokaklardan uzak tutan nedenlerin ne olduğu araştırılmıştır. Güvenlik konusu üzerine düzenlenen sorular ile daha tutarlı sonuçlar elde edilmiştir. "Oturduğunuz mahallede güvenlik problemleri yaşanıyor mu?" sorusuna alınan yanıtlar neredeyse \% 100 oranında Muratpaşa Mahallesinde güvenlik problemleri olduğu iddiasını kanıtlamaktadır. \% 49,1 oranında verilen 'nadiren" yanıtı ve \% 47,2 oranındaki 'evet, s1k s1k" yanıtı Şekil 21' de gösterilmiştir.

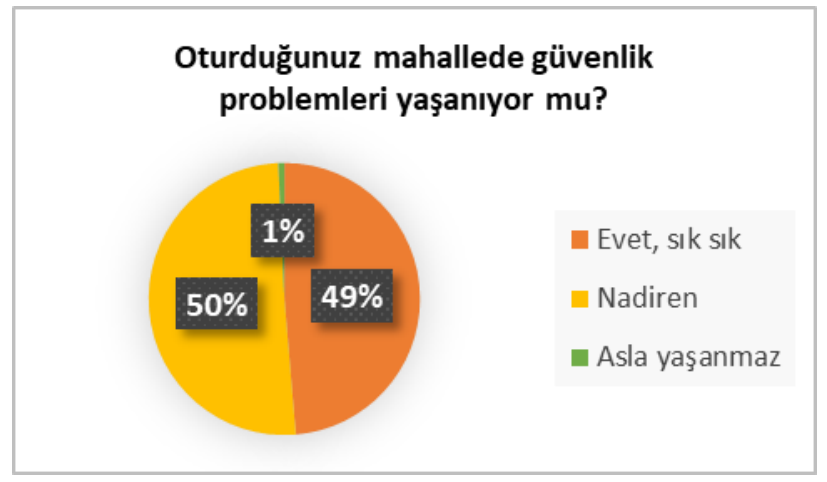

Şekil 21. Güvenlik durumunu gösteren grafik

8. anket sorusu ve yanıtları ise mahalle halkının yaşadığı çevreye karşı olan aidiyet hissi hakkında fikir vermektedir. Kullanıcıların \% 49,1 'i mahallede yürürken kendini endişeli hissedip, hızlı adımlar atarak yürümeye gayret etmektedir. Bunun en önemli göstergesi de yine kullanıcı davranışlarında analizinde ve gece ışıklandırma analizinde ele alınan güvenlik hissinden yoksunluktur. Bir insanın bir mekânı kullanırken kendini orada huzursuz hissettiği zaman bir an evvel oradan uzaklaşma isteği taşıması ile mahalle halkının yaşadığı durum aslında oldukça benzerdir. $\mathrm{Bu}$ durumun temelinde güvenlik problemleri yatmaktadır. \% 35,8 gibi bir oran ile bir his taşımadan yürüyen kullanıcılar ise yine mekâna aidiyet hissindeki eksikliğin yüksek seviyede olduğunu kanıtlamaktadır. Sadece \% 15,1 oranında bir kullanıcı grubunun ise mahalle halkıyla selamlaşarak ve konuşarak rahatça yürümesi ise tüm bu şartlar altında olumlu görülebilecek bir veridir. Elde edilen sonuçlar Şekil 22. 'de gösterilmektedir.

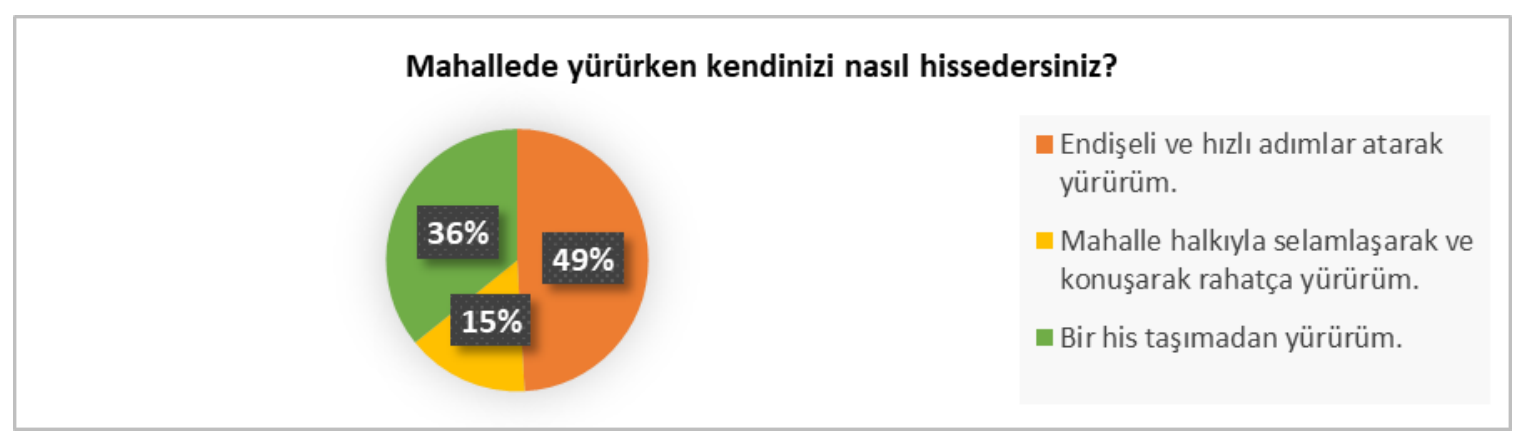

Şekil 22. Kullanıcıların mahalle kullanımı sırasındaki hislerini gösteren grafik

Muratpaşa Mahallesi halkı ile yapılan anket çalışmasının bir sorusu da ' 'kahvehane kültürü' üzerine değerlendirme yapmaya yardımcı olmuştur. Muratpaşa Caddesi ve Erzincankapı Sokağı üzerinde yer alan yüksek yoğunluklu kahvehaneler, kıraathaneler ve oyun salonlarının mahalle halkı tarafindan değerlendirilmesi sağlanmıştır. ' 'Mahallenizde mevcut olan kahvehane kültürü sizi rahatsız ediyor mu?', sorusuna alınan yanıtların \% 66 oranı ile en yükseği "evet, rahatsızlık duyuyorum" yanıtıdır. Elde edilen bu sonuç kullanıcı davranışı analizinde belirlenen düşük ve belirli noktalarda sıfıra düşen kadın kullanıcı yoğunluğu ile ilişkilidir. \% 17'lik eşit oranlar ile 'hayır, rahatsızlık duymuyorum" ve "emin değilim" yanıtları alınmıştır (Şekil 23.). 


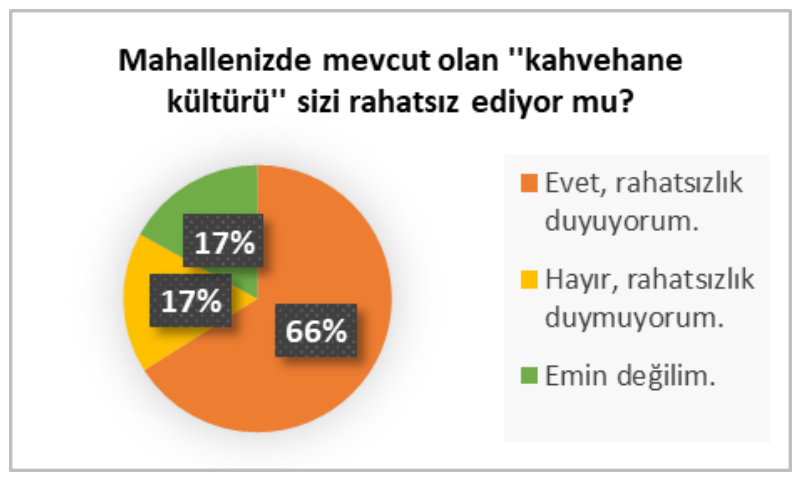

Şekil 23. Kahvehane kültürünün mahalledeki etkisini gösteren grafik

Kadın ve erkek kullanıcılarla yürütülen anketin son sorusu ise açık uçlu cevap yöntemiyle hazırlanmıştır. Soruyu yanıtlamak istemeyen kullanıcılar olduğu gibi mahalle hakkındaki genel yargıları doğrulayan yanıtlar da alınmıştır. "Mahallenizde daha nitelikli bir yaşam için önerileriniz var mı? " sorusuna alınan yanıtlar şöyledir;

- 'Bir bayan olarak sayıları her geçen gün artan, sokaklarda adım atamayacak kadar çok alan kaplayan ve rahatsızlı veren kahvehanelerin kaldırılmasını istiyorum."

- "Kahvehanelerin dükkân dışına taşması beni rahatsız ediyor."

- "Mahallemizde görsel açıdan daha zevkli mekânlar olmasını isterdim."

- "Keşke mahalle yıkılıp yeni baştan imar edilip daha nezih bir yaşam oluşturulsa."

- "Kahvehanelerin kaldırılmasını ve insanların sokaklarda rahatça yürüyebilmesi. Kadın ve çocuklar için, dolayısıyla aileler için aktivite alanlarının olması. Önünden geçerken rahatsızlık duyduğumuz iş yerlerinin kapat1lması.",

- "Kahvehanelerin taşınması çünkü oralarda uyuşturucu ticareti yapıldığını duyduk ve endişe etmeye başladık. Ayrıca planlı bir kentsel dönüşüm yapılmalı zira cadde ve sokaklar çok dar ve çok çirkin bir görüntüye sahip."

- "Güvenlik tedbirleri arttırılmalı çünkü bir kadın olarak kendimi bazı noktalarda güvensiz hissediyorum.",

- "Akşam ve gece vakitlerinde güvenlik problemleri yaşanmakta olduğu için güvenlik önlemleri alınmalı.",

- "Uzun yıllardır burada yaşıyorum ancak son 6-7 yıldır sayısı artan ve sokaklara taşan kahvehaneler, kadınlar olarak bizi zor duruma sokuyor kendimizi güvensiz hissediyoruz."

- "Kahvehanelerin kaldırılması. Daha geniş kaldırımlar yapılarak yaşayan halkın rahatının sağlanması.',

- "Kahvehanelerin kaldırımlara ve sokak ortalarına kadar taşmasına engel olunmalı. Sokaklar ortak kullanım alanı olmasına rağmen kadının yürüyememesi için çokça neden var."

- 'Şehrin merkezi olmasına rağmen çöküntü bölgesi olmak üzere olan bir mahalle olduğunu ve üzerine insan profili düzeyli çalışmalar yapılması gerektiğini düşünüyorum."

- "Kentsel dönüşüm sayesinde şehir merkezi hem daha cazip hale gelecektir hem de yaşam profili iyileşecektir."

Anketin son sorusuna verilen yanıtlar Erzurum kenti Muratpaşa Mahallesinde belirlenen çalışma içinde yapılan tüm analizlerinden ve anket çalışmasından elde edilen sonuçların özeti niteliğindedir. Verilen cevaplar genel olarak mahalledeki güvensizlik hissiyle birlikte bu hissin oluşmasında büyük etkisi olan kahvehane kültürünün ve son dönemlerde mahallede yaşanan kültürel değişimlerin olduğunu göstermektedir. Ayrıca karanlık sokakların var olduğu ve alınması gerekli görülen çeşitli güvenlik önlemlerinin kullanıcılar tarafından dile getirilmesi de anketin bir diğer genel sonucudur. Kullanıcılar genel bir güvensizlik hissetmekte ve bunu ifade etmektedirler. Bunların yanında çeşitli aktivite alanlarının olmasını ve bu alanları genç, yaşlı, çocuk, kadın ve erkek tüm kentlilerin kullanabilmesini hayal etmektedirler. Kentsel dönüşüm ve görsel iyileştirmelerin de alanın kullanım seviyelerini iyileştireceğine dair görüşler de anketin bir diğer sonucudur.

\section{SONUÇ:}

Kentsel mekânlarda, toplumsal yapının meydana getirdiği çeşitli sosyo-kültürel değişıim ve dönüşümler mevcuttur. Bu

Evaluation of Women's Behaviours in Urban Public Spaces in terms of Security: the Sample of Muratpaşa Neighbourhood, Erzurum

Journal of Urban Academy | Volume: 14 Issue: 3 | ISSN: 2146-9229

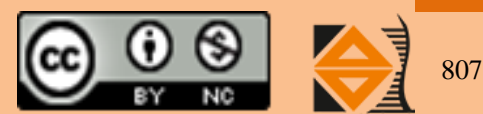


değişim ve dönüşümler genellikle kadınların yaşam alanlarını etkin kullanmalarını sınıllandırmaktadır. Toplumsal baskı ve yanlış yargılar ile değersiz görülen ve ötelenmelere maruz bırakılan kadınlar kentsel mekânlarda güvenlik problemleri de yaşamaktadır.

Erzurum Kenti Yakutiye İlçesi Muratpaşa Mahallesinde yaşanan güvenlik problemleri, kentsel mekânların kullanım durumları ve kadın kullanıcıların sınırlılıklar yaşayarak kullanmak zorunda kaldıkları alanlar bu çalışma ile incelenmiştir. Yapılan analizler ve yürütülen anket çalışması ile kadınların alanı etkin şekilde kullanamadığı ve çeşitli güvenlik endişeleri taşıdıkları sonucuna ulaşılmıştır. Ara sokakların kullanımının kadın kullanıcılar tarafından düşük yoğunlukta olması ve kullanım seviyeleri düşük olan ara sokakların ışıklandırma konusunda da yeterli düzeyde olmaması mahallenin güvenlik sorunlarına sahip olduğunu kanıtlamaktadır. Kadınlar tarafından kullanılmayan sokak ve caddeler üzerindeki kentsel mekân fonksiyonları ele alındığında ise alanda kahvehanelerin yoğunlukta olduğu ve bu kültürün alanın genelinde hakim olduğu görülmektedir. Kahvehanelerin etkisiyle erkek kullanıcıların mekân kullanımının yüksek seviyelerde olduğu da analiz çalışmaları sonucunda tespit edilmiştir. Kadınların mahalleyi gece kullanım durumu analiz edilirken incelenen aydınlatma elemanlarının varlıklarının ve niteliklerinin yetersiz olduğu görülmüştür. Ayrıca tamamen karanlık sokakların var olması da güvenlik hissi düzeyini düşürmektedir.

Yürütülen anket çalışmasının çıktıları da yapılan tüm analiz çalışmalarını desteklemektedir. Mahalle halkı güvenlik problemleri yaşadıklarını ve mevcut kahvehanelerin varlığından rahatsızlık duyduklarını objektif şekilde dile getirmiştir. Kentsel mekânlarda yaşanan güvenlik endişelerinin ve benzeri problemlerin; toplumsal kültür öğelerinin doğru kullanılmaması, geleneksel toplum yapısının çeşitli olumsuz etkileri, fiziksel aydınlatma elemanlarının yetersiz veya niteliksiz kullanımı gibi sebeplere dayandığı sonucu görülmektedir. Anketin diğer bir sonucu ise aktivite alanlarının yetersizliğiyle birlikte kentsel mekânların fiziksel da olarak niteliksiz olduğu yönünde yapılan değerlendirmelerdir.

Bu çalışmada elde edilen verilere göre;

- Kentsel mekânların tüm bireyler tarafından etkin kullanımı için bilinçli toplumsal bir yapı ile nitelikli kentsel çalışmaların yürütülmesi gerekmektedir.

- Kentlerin görünmeyen tarafı gibi algılanan ara sokakların doğru özellikte ve nitelikte elemanlar ile aydınlatılması önerilmektedir.

- $\quad$ Kentlerdeki mahalleler ve diğer kentsel birimlerdeki kültürel yapı doğru okunarak halkın etkin rol alabileceği kentsel mekânlar kurgulanmalıdır.

- Kadın, erkek, çocuk ve yaşlı gibi ayrımlar yapılmadan her bireyin etkin rolünün olduğu planlama çalışmaları yürütülmelidir.

- Kadınların kentle olan ilişkisini güçlendirecek ve her kullanıcı için eşit imkânlara sahip kentsel mekânlar kurgulanması gerekmektedir.

Bu çalışma ile Muratpaşa Mahallesi kentsel mekânında mevcut durum tespiti sağlanarak son dönemlerde önemli düzeye ulaşan kent ve kadın konulu araştırmalara önemli bir katkı sağlanacaktır. Kentli hakları, kadın hakları, toplumsal etkileşimler, cinsiyetçi mekân ayrışımları ve kentsel mekânların kullanıcılarına göre tasarımları/ dağılımları gibi konular ile mevcut araştırma genişletilerek daha kapsamlı bir literatür katkısı sağlanması hedeflenmektedir.

\section{Etik Standart ile Uyumluluk}

Çıkar Çatışması: Yazarlar herhangi bir çıkar çatışmasının olmadığını beyan eder.

Etik Kurul İzni: Bu çalışma için etik kurul iznine gerek yoktur.

Finansal Destek: Bulunmamaktadır.

Teşekkür: Yürütülen analiz çalışmalarındaki desteklerinden ötürü Mimar Seçil YUMLU ve Şehir Plancısı Burcu ADIGÜZEL'e teşekkür ederim.

\section{KAYNAKÇA:}


Aksoy, E. (2007). Suç ve Güvenli Kent Yaklaşımı. Dosya 06/ Kent ve Suç, Aralık(55), 11-15. http://www.mimarlarodasiankara.org/dosya/dosya6.pdf

Aktaş, G. (2017). Kadın Açısından Kente İlişkin Mekân Pratikleri. Pamukkale Üniversitesi Sosyal Bilimler Enstitüsü Dergisi, 27, 136-149.

Aktürk, E. Et Al. (2012). 81 İlde Kültür ve Şehir Erzurum. Kültür Konseyi Derneği, s.394. İstanbul.

Arık, H. (2009). Kahvehanede Erkek Olmak: Kamusal Alanda Erkek Egemenliğinin Antropolojisi. Cins Cins Mekân, 168- 201. Varlık Yayınları. İstanbul.

Aydoğan, B. (1997). Mehmet Akif Ersoy’un Meyhane Ve Mahalle Kahvesi Şiirleri Üzerine Bir Değerlendirme, Türkoloji Araştırmaları, 85-106. Adana.

Cantek, F.Ş., Ulutaş, Ç.Ü., Çakmak S. (2014). Evin İçindeki Sokak, Sokağın İçindeki Ev: Kamusal ile Özel "ara"sında Kalanlar, Kenarın Kitabı, 121 - 159. İletişim Yayınları. İstanbul.

Doan, P. L. (2007). Queers in the American City: Transgendered Perceptions of Urban Space. Gender, Place and Culture. 14(1), 57-74.

Durmaz, U. (2020). Bir Mekânın Anatomisi: Halk Edebiyatı Ürünlerinin Yaratma ve İcra Ortamı Olarak Kahvehaneler. Uluslararası Halkbilimi Araştırmaları Dergisi, Cilt 3 Sayı 4, 110-129.

Ediz, İ. (2008). Osmanlı'dan Cumhuriyet'in İlk Yıllarına Kahvehaneler Ve Sosyal Değişim. Sakarya Üniversitesi Fen Edebiyat Dergisi. 10-1, 179-189.

Erdönmez, E., \& Çelik, F. (2016). Kentsel Mekânda Kamusal Alan İlişkileri. Türkiye Bilimler Akademisi Kültür Envanteri Dergisi, 14,145-163.

Eşkinat, Y. (1992). Kent Planlama ve Tasarım Arasında Gerekli Ara Ölçek: Kentsel Tasarım. II. Kentsel Tasarım ve Uygulamalar Sempozyumu, İstanbul.

Griffin, S. (1986). Rape: The Politics of Consciousness. San Francisco: Harper \& Row Limited

Güney, E. M., Tezcan, S., Ağın, C. (2020). Being Able to Exist in the City In Defiance of Planning: An Examination on a Woman-Friendly City in İzmir- Konak. Planlama Dergisi. 30(2), 273-293.

Kaypak, Ş. (2016). Kentsel Bir Sorun Olarak Kentsel Güvenlik. The Journal of Academic Social Sciences, Say1:33, 35-50.

Low, S. \& Smith, N. (2006). The Politics of Public Space. New York: Routledge.

Lynch, K. (1960), The Image of the City, The MIT Press, Cambridge.

Maslow, A. (1968). Motivation and Personality, Harber Publishing, New York.

Özkök, E. (2019). Bir Erkeklik Mekânı Olarak Kahvehaneler. Yüksek Lisans Tezi. Hacettepe Üniversitesi Sosyal Bilimler Enstitüsü Sosyoloji Anabilim Dalı Kadın ve Toplumsal Cinsiyet Çalışmaları Yüksek Lisans Programı. Ankara.

Sancar, S. (2013). Erkeklik: İmkansız İktidar Ailede, Piyasada ve Sokakta Erkekler. Metis Yayınları. İstanbul.

Temizarabacı, Y. (2005). Ütopyanın Kadınları-Kadınların Ütopyası. Sel Yayıncılık. İstanbul.

Tuncer, S. (2015). Dışarı Çıkmak: Özelden Kamusala. Moment Dergi, 2(2), 30-58. 
Url 1: Google Haritalar, https://www.google.com/maps/@39.9039784,41.2713221,1194m/data=!3m1!1e3 (Erişim Tarihi:01.06.2019)

Url 2: TÜİK, http://www.tuik.gov.tr/(Erişim tarihi 12.01.2020 09:25).

Url 3: TÜİK, http://www.tuik.gov.tr/(Erişim tarihi 12.06.2019 16:35).der

Url 4: Kaya, E. (2008). Kent Güvenliğinin Sağlanması, (19-22). http://www.yerelsiyaset.com/pdf/2008/4.pdf, (Erişim Tarihi: 28.04.2011)

Url 5: Kirk, D. (2010). Women friendly Seoul Project. Retrieved from http://www. biztechreport.com/story/423women-friendly-seoul.

Women in Cities International, (2008). Women's Safety Audits: What Works and Where?. Nairobi, Kenya: UNHabitat Safer Cities Program 